Running head: School-bullying and Cyber-bullying

\title{
Comparing factors related to School-bullying and Cyber-bullying
}

\author{
Calli Tzani-Pepelasi ${ }^{1}$, Dr. Maria Ioannou ${ }^{1}$, Dr. John Synnott $^{1}$, Sally-Ann Ashton ${ }^{2}$ \\ ${ }^{1}$ Department of Psychology, School of Human and Health Sciences, University of \\ Huddersfield, UK \\ ${ }^{2}$ Department of Applied Health and Social Care, Faculty of Health and Social Care, Edge \\ Hill University, UK
}

Corresponding author: Calli Tzani-Pepelasi

Department of Psychology, School of Human and Health Sciences, International Research Center for Investigative Psychology (IRCIP), University of Huddersfield, Queensgate, Huddersfield, HD1 3DH, UK

Telephone: +447450266298 .

Fax: +44 (0) 1484473760

Email address: Kalliopi.Tzani-Pepelasis@hud.ac.uk

Dr. Maria Ioannou

Department of Psychology, School of Human and Health Sciences, International Research Center for Investigative Psychology (IRCIP), University of Huddersfield, Queensgate, Huddersfield, HD1 3DH, UK,

Telephone: +44 (0)1484 471174

Fax: +44 (0) 1484473760

Email address: $\underline{\text { M.Ioannou@ @ud.ac.uk }}$ 
Running head: School-bullying and Cyber-bullying

\section{Dr. John Synnott}

Department of Psychology, School of Human and Health Sciences, International Research Center for Investigative Psychology (IRCIP), University of Huddersfield, Queensgate,

Huddersfield, HD1 3DH, UK,

Telephone: +44 (0)1484 471174

Fax: +44 (0) 1484473760

Sally-Ann Ashton

Department of Applied Health and Social Care, Faculty of Health and Social Care, Edge Hill University, St Helen's Road, Ormskirk, L39 4QP, UK

Telephone: +44(0)1695657087

Email address: Ashtons@edgehill.ac.uk 
Running head: School-bullying and Cyber-bullying

\begin{abstract}
Purpose: To present a comparative summary of literature of the risk and preventative factors related to school bullying (SB) and cyber-bullying (CB), while identifying research gaps. Background: Literature on bullying appears to disagree whether CB should be considered as a different form of bullying or as a subtype of SB. Researchers, in an attempt to understand bullying, examined in depth numerous risk and preventive factors.

Methods: Based solely on previous research papers, fourteen risk and preventative factors related to $\mathrm{SB}$ and likewise to $\mathrm{CB}$, were selected on the basis that are most commonly indicated as strong factors in preceding works; each factor was searched for in relation to SB and CB separately, allowing a comparison of how each factor relates to SB and likewise to CB.

Conclusions: Findings present a comparative picture of the factors related to SB and CB and provide a direction in the area of factors for fellow researchers wishing to develop antibullying strategies in the future. As expected the present study found that some factors are similarly related to $\mathrm{SB}$ as to $\mathrm{CB}$, and others differentiate. Details of findings, limitations and implications are further discussed.
\end{abstract}

Key words: School-bullying, Cyber-bullying, Bullying, Risk Factors, Preventive Factors. 
Running head: School-bullying and Cyber-bullying

\section{Introduction}

Although research on school-bullying (SB) (Besag, 1989; Stephenson \& Smith, 1989;

Olweus, 1993; Morahan-Martin \& Schumacher, 2003; Olweus, 2003; Conners-Burrow, Johnson, Whiteside-Mansell, Mckelvey \& Gargus, 2009; Cowan, 2012; Finkelhor, Turner \& Hamby, 2012; Beckman, Hagquist \& Hellstrom, 2013; Puhl \& King, 2013; Hellstrom, Persson \& Hagquist, 2015) and cyber-bullying (CB) (Nishina, Witkow \& Juvonen, 2005; Willard, 2006; Rigby, 2007; King, Walpole \& Lamon, 2007; Thompson \& Cupples, 2008; Mishna, Saini \& Solomon, 2009; Nuccitelli, 2012; Lapidot-Lefler \& Barak 2012; Yang, Stewart, Kim, Kim, Shin, Dewey \& Yoon, 2013; Tarablus, Heiman \& Olenik-Shemesh, 2015) is quite extensive, nonetheless, researchers (Van der Wal Marcel, 2005; Gerler, 2008) express the need for more empirical work on these subjects, mainly driven by the severity of consequences affecting both victims and perpetrators (Bennett, Holloway \& Farrington, 2008; Kaltiala-Heino \& Frojd, 2011; Rokach, 2000; Rokach, 2001).

Huang and Chou (2010) reported that SB differs from CB, while others (Juvonen \& Gross, 2008) disagreed. Apart from the difficulty to control CB (Slonje, Smith \& Frisen, 2013) the use of social media and the use of electronic devices differentiate CB from SB. Particularly, one single CB act can reach the far ends of the earth in a matter of minutes (David-Ferdon \& Hertz, 2007; Lenhart, Madden, Macgill, \& Smith, 2007; MacDonald \& Roberts-Pittman, 2010; Mark \& Ratliffe, 2011; Frisen, Hasselblad \& Holmqvist, 2012; Bauman \& Baldasare, 2015; Harrison, 2015; Kokkinos, Baltzidis \& Xynogala, 2016), while the perpetrators are often protected from the anonymity offered in cyberspace (Kraft \& Wang, 2009; Jose, Kljakovic, Scheib \& Notter, 2012; Bauman \& Newman, 2013; Boulton, Hardcastle, Down, Fowles \& Simmonds, 2014; Cross, Lester \& Barnes, 2015).

Factors for the present review were selected on account of their potential to directly or indirectly be manipulated and incorporated in anti-bullying strategies. The selected factors 
Running head: School-bullying and Cyber-bullying

were: parent connectedness, style of parenting and monitoring, sibling support, family teasing about appearance, friendship quality, empathy, self-esteem, aggression, anger, impulsivity, self-control, guilt, morality, and coping skills.

To be included in the review articles had to meet the following criteria: 1 . The study was published and peer reviewed. 2. The study was written in English or translated in English. Abstracts of the peer-reviewed articles were inspected to ensure that the works met the inclusion criteria. In total this study identified 172 works that incused information about the factors examined in this review. The present paper will present a review of the literature on school bullying and cyber bullying; it will then offer a comparative discussion before considering the implications of current research findings for strategies to reduce bullying.

\section{School Bullying}

Research into school bullying (Roland, 2002) has identified the following categories: (a) physically harming a person or indirect forms of victimisation, including making fun of, excluding, and/or spreading rumours about a person; (b) victimisation that occurs repeatedly over time; and (c) unequal strength between victims and perpetrators (Craig, 1998; CarboneLopez, Esbensen \& Brick, 2010). Prevalence rates differ amongst studies (Cankaya \& Tan, 2011; Cambell, Spears, Slee, Kift \& Butler, 2011); and vary from $12.1 \%$ for bullying behaviour (Scheithauer, Hayer \& Petermann, 2006) to $43 \%$ of similar bullying tactics (Raskauskas, 2009; 2010), and up to $46.6 \%$ for victimisation (Fleming \& Jacobsen, 2009).

\section{Family and social networks}

Family support is a protective factor for victimisation from bullying (Duong \& Bradshaw, 2014); parent and children connectedness, communication, and parental involvement in children's lives, have been extensively studied in relation to bullying 
Running head: School-bullying and Cyber-bullying

(Matsunaga, 2009; Loukas \& Pasch, 2013; Morin, Bradshaw \& Berg, 2015). However, parents are rarely involved in anti-bullying strategies (Cross \& Barnes, 2014), which can pose a risk for parental unawareness (Mann, Kristjansson, Sigfusdottir \& Smith, 2015). Parents' perspectives on SB differentiates from children's perspective (Holt, Kaufman Kantor \& Finkelhor, 2009), in such a way that often parents are not aware of their children's involvement in either perpetration or victimisation.

Wienke Totura, MacKinnon-Lewis, Gesten, Gadd, Divine... and Kamboukos (2009; 2008) advised that parents play an influential role. As supported by research by Atik and Guneri (2013), which indicated associations between low parental strictness/supervision and the likelihood of being a victim; and equally between low parental acceptance/ involvement, strictness/supervision, and the likelihood of being a bully/victim. Parental communication, involvement and monitoring are considered aspects of parenting style (Van der Watt, 2014). Broadly, literature shows that parenting styles that include support, affection and communication reduce SB perpetration and victimisation (Aslan, 2011; Rajendran, Kruszewski \& Halperin, 2016). Whereas disciplinary behaviors that include psychological control (Gómez-Ortiz, Del Rey, Casas \& Ortega-Ruiz, 2014) and parental psychological aggression, pose as risk factors for victimisation (Gómez-Ortiz, Romera \& Ortega-Ruiz, 2016).

There has been very little research on the role of sibling support for victims of bullying (Bourke \& Burgman, 2010). Regardless, Bowes et al (2010) reported that family factors, such as maternal warmth and sibling warmth, are associated with children's resilience to bullying victimisation. Hadfield, Edwards and Mauthner (2006) reported that younger students feel that having a sibling at school is a source of support when victimised; whereas, older students believe that their younger siblings cause them difficulties at school. Elder siblings long for sibling separateness during school hours, while younger siblings 
Running head: School-bullying and Cyber-bullying

expect their older siblings to provide protection.

Sibling violence is unfortunately the least examined form of family violence (Krienert and Walsh, 2011). Hoetger, Hazen and Brank (2015) found that sibling teasing can be more common than peer bullying; with rates up to $78 \%$ for sibling victimisation and up to $85 \%$ perpetration (Skinner \& Kowalski, 2013). Likewise, Tucker, Finkelhor, Turner and Shattuck (2014) reported that $15 \%$ of their sample had been victimised by both a sibling and peer; sibling victimisation was more common in childhood than adolescence and also predicted peer victimisation. Sibling aggression is a strong factor for involvement in peer bullying (Rose, Simpson \& Ellis, 2016). Victimisation by a sibling significantly increases the odds of peer victimisation, and the perpetrators of sibling aggression are more likely to be both peer bullies and bully- victims (Tippett \& Wolke, 2015).

Research has indicated an association between friendship quality and SB. In general, results show that friendship quality moderates children's behavior with a tendency for externalising problems in the form of bullying, but protects them from peer victimisation (see Bollmer et al., 2005; Woods, Done \& Kalsi, 2009; Kendrick, Jutengren \& Stattin, 2012). Moreover, Jantzer, Hoover and Narloch (2006) indicated an association between higher levels of perceived bullying with lower levels of friendship satisfaction and vice versa. While, Mishna, Wiener and Pepler (2008) warned that when it comes to investigating friendship in relation to SB, researchers should also include SB victimisation by friends.

\section{Individual characteristics}

The relationship between empathy and bullying has been extensively studied (Smith, 2006; Singer \& Lamm, 2009; Espelage, Green \& Polanin, 2012; Einolf, 2012; Mitsopoulou \& Giovazolias, 2015). Empathy includes: a) cognitive, which refers to the ability to identify and understand other peoples' emotions. And b) affective, which refers to the feelings people 
Running head: School-bullying and Cyber-bullying

might experience in response to others' emotions (Jolliffe \& Farrington, 2006). In general, findings appear congruent (Muñoz, Qualter \& Padgett, 2011; Ciucci \& Baroncelli, 2014), and report that low empathy is associated with bullying behaviour, particularly for males (Jolliffe \& Farrington, 2006). Specifically, Stavrinides et al (2010) reported that there is a negative relationship between a child's ability to empathise, and their ability to bullying others. In terms of sex differences, the affective aspect of empathy is associated with bullying for males but not for females (Jolliffe, \& Farrington, 2011; Topcu \& Erdur-Baker, 2012).

Age can be a factor. Khanjani, Mosanezhad Jeddi, Hekmati, Khalilzade, ... and Ashrafian (2015) found that affective empathy increases with age. A common finding amongst the studies was that victimisation is negatively associated with cognitive empathy, but not with affective empathy (Noorden, Haselager, Cillessen \& Bukowski, 2015). Finally, Garandeau, Vartio, Poskiparta and Salmivalli (2016) found that making bullies feel empathy for the victim and condemning their behavior encourages desistance, but blaming the bully is ineffective and can lead to the opposite outcome.

Self-esteem as a factor for SB has been comprehensively studied (Rigby \& Cox, 1996; Brito \& Oliveira, 2013), but findings vary (Tsaousis, 2016). Self-esteem can be viewed as both an antecedent and a consequence of victimisation (McMahon, Reulbach, Keeley, Perry \& Arensman, 2010; Drennan, Brown \& Sullivan Mort, 2011). Some studies (Salmivalli, Kaukiainen, Kaistaniemi \& Lagerspetz, 1999) found a stronger association for boys than girls. Others (Karatzias, Power \& Swanson, 2002) found that bullies exhibit higher levels of peer self-esteem than victims, but in general categories exhibit significantly lower global self-esteem than non-involved in bullying children (O’Moore \& Kirkham, 2001; Marini, Dane \& Bosacki, 2006; Atik \& Güneri, 2013). Literature also presents mediators in this association, such as physical appearance, body dissatisfaction (Fox \& Farrow, 2009), sex 
Running head: School-bullying and Cyber-bullying

differences (Pollastri, Cardemil \& O’Donnell, 2010) and high narcissism (Finaly, Fanti \& Henrich, 2015).

Aggression is a strong factor in bullying (Catanzaro, 2011; Ireland \& Archer, 2004; Homel, 2013; Thornton, Frick, Crapanzano \& Terranova, 2013), with boys engaging more in physical aggression and girls in verbal aggression (Craig, 1998). Some studies (Roland \& Idsøe, 2001) examined aggression in terms of proactive and reactive aggression, and how these aspects present an impact on SB. The findings informed that both proactive and reactive aggressiveness are related to SB perpetration, with proactive aggression showing a stronger association. However, older individuals exhibit more proactive aggression in terms of SB perpetration; while for victimisation this association is weak. In addition, Lee (2009) found that aggressive boys are likely to be rejected by peers, whereas aggressive girls are both rejected and accepted by peers (Lansu, Cillessen \& Bukowski, 2013).

Although anger and aggression are often studied together (Gresham, Melvin \& Gullone, 2016), nonetheless these two factors are different aspects. Anger refers to the emotion one experiences (Kashdan, Goodman, Mallard \& DeWall, 2015), while aggression refers to the act (Wilkowski \& Robinson, 2008; 2007). Nonetheless, like aggression, anger also is a strong predictor for perpetration (Hein, Koka \& Hagger, 2015; Tanrikulu \& Campbell, 2015); explicitly, the higher the anger level, the higher the likelihood of perpetration (Bosworth, Espelage \& Simon, 1999). Smits and Kuppens (2005) incorporated anger as a trait and concluded that without the right coping skills, anger results in aggression (Ramírez \& Andreu, 2006).

There is a direct positive link between bullying and anger (Sigfusdottir, Gudjonsson and Sigurdsson, 2010); for both perpetration and victimisation (Rieffe, Camodeca, Pouw, Lange, \& Stockmann, 2012). Turner and White (2015) revealed that the highest levels of reactive aggression are observed to occur for men who are high on anger rumination, thus 
Running head: School-bullying and Cyber-bullying

more perpetration; while the lowest levels of reactive aggression are found for women low on anger rumination. Likewise, Malik and Mehta (2016) reported that male bullies experience more anger than girls, thus suggesting a strong association between anger and SB for boys. Impulsivity in association to SB has been examined in depth (Fanti \& Kimonis, 2012; Erreygers, Pabian, Vandebosch \& Baillien, 2016; Chen \& Chng, 2016), and the general notion is that impulsivity is a strong factor for SB perpetration (Espelage, Bosworth \& Simon, 2001; Oluyinka, 2008; Holland et al, 2009) with high impulsivity being related to all forms of bullying for both genders (Jolliffe \& Farrington, 2011). Lack of self control equals impulsivity (Archer \& Southall, 2009). Low levels of self control in youth are also associated with the perpetration of physical and psychological bullying (Moon and Alarid, 2015). Although other research (Chui \& Chan, 2013; Chui \& Chan, 2015; 2014) has indicated a negative association between perpetration and self-control, there was no association between victimisation with self-control.

Moral emotions and particularly guilt and shame have also been examined as factors associated with SB (Ttofi \& Farrington, 2008; Mazzone, Camodeca \& Salmivalli; 2016a; Mazzone, Camodeca \& Salmivalli, 2016b). Specifically, guilt involves a sense of tension, remorse and regret over a hurtful act; while shame, is an acutely painful emotion that is typically accompanied by a sense of worthlessness and powerlessness (Menesini, Sanchez, Fonzi, Ortega, Costabile \& Lo Feudo, 2003). Some research (Ahmed \& Braithwaite, 2004) has found that bullies are less likely to acknowledge shame and more likely to displace it, and are also less likely to experience guilt. Whereas others (Menesini and Camodeca, 2008) have concluded that bullies do not do not experience guilt or shame in moral situations because they do not sympathise with the victim or feel responsible for the harm caused.

Although guilt is a positive and adaptive emotion, in the sense that it motivates prosocial behavior towards the victim, it can cause people to neglect the well-being of others in 
Running head: School-bullying and Cyber-bullying

their social surroundings; in repairing one relationship they may damage another (Hooge, Nelissen, Breugelmans \& Zeelenberg, 2011). Such findings leave researchers indecisive whether they should enhance guilt and shame in terms of SB intervention strategies. For example, Ahmed and Braithwaite (2012) informed that shame management is supposed to be part of the healing process, which is a goal in restorative justice. Similarly, Olthof (2012) informed that guilt is positively related to pro-social behavior, while less guilt is associated with increased age and it found that only in the presence of adults is shame is negatively related to antisocial behavior and positively to outsider behavior.

Moral disengagement is associated with SB perpetration (Hymel \& Bonanno, 2014; Sims-Schouten, 2015); however, guilt and shame are not the only emotions that constitute our moral values (see Horton, 2011; Price, 2012; Menesini, Nocentini \& Camodeca, 2013; Pozzoli, Gini \& Vieno, 2012; Thompson, 2013). Obermann (2011) revealed that both selfreported and peer-nominated bullying associate to moral disengagement and that both pure bullies and bully-victims display higher moral disengagement than non-involved in bullying children; whereas, Perren and Gutzwiller-Helfenfinger (2012) indicated that a lack of moral values and a lack of remorse predicts both SB and CB. Others (Caravita, Gini \& Pozzoli, 2012) showed that acceptance of moral transgression and moral disengagement is associated to SB among early adolescents only, with moral disengagement in childhood relating to defending among girls. Moreover, it is possible that popular children bully others and perceive their actions as a reward leading to high-perceived popular status (Kollerová, Janošová \& Ř́ícan, 2015). Similarly, Thornberg and Jungert (2014) who added the effect of gender and age, suggested that compared to girls, boys express significantly higher levels of moral justification, euphemistic labeling, diffusion of responsibility, distorting consequences, and victim attribution; with younger children and girls being more likely to defend victims. 
Running head: School-bullying and Cyber-bullying

\section{Coping skills}

For this factor, the general notion in literature is that that emotionally oriented coping strategies create higher risk for victimisation, and problem-solving strategies protect them (Baldry \& Farrington, 2005; Konishi \& Hymel, 2009; 2008). Victims use mostly problemfocused coping strategies, with boys using externalising strategies with greater frequency than girls, and girls seeking social support more often than boys (Hunter \& Boyle, 2004; Tenenbaum, Varjas, Meyers \& Parris, 2011; Garnett, Masyn, Austin, Williams \& Viswanath, 2015; Ramirez, 2013). Polan, Sieving and McMorris (2013) informed that of socialemotional skills indicators, interpersonal skills and stress management skills demonstrate significant bivariate relationships with each of the bullying and violence outcomes; whereas, greater interpersonal skills and greater stress management skills are significantly associated with lower odds of violence involvement. The latter finding presenting greater stress management skills as a protective factor for involvement in violence is of great importance. Goldsmid and Howie (2014) suggested that distress predicts higher levels of victimisation. In terms of perpetration only, Trémolière and Djeriouat (2016) revealed that a sadistic personality trait predicts minimisation of the importance of causal mechanisms to harmful consequences in moral judgment.

\section{Cyber Bullying}

CB emerged with the evolution of technology and children's access to cyberspace (DePaolis, \& Williford, 2015) and has equally severe consequences as SB (Agatston, et al., 2007). CB definition has taken many forms (Cesaroni, Downing \& Alvi, 2012); the most common classification presents $\mathrm{CB}$ as purposefully and repetitive harming others through electronic devices (Rigby, 2002; Hinduja \& Patchin, 2008; Pepler, Jiang, Craig \& Connolly, 2008; Turan, Polat, Karapirli, Uysal \& Turan, 2011; Mura, Topcu, Erdur-Baker \& 
Running head: School-bullying and Cyber-bullying

Diamantini, 2011; Modecki, Minchin, Harbaugh, Guerra \& Runions, 2014). Prevalence rates vary (Rivers \& Noret, 2010; Mishna, Cook, Gadalla, Daciuk \& Solomon, 2010; Rigby \& Smith, 2011; Chang, Lee, Chiu, Hsi, Huang \& Pan, 2013; Messias, Kindrick \& Castro, 2014; Hemphill, Kotevski \& Heerde, 2015) with some studies (Modecki, et al., 2014) reporting rates up to $31.5 \%$ for cyber perpetration and up to $56.2 \%$ for cyber victimisation.

\section{Family and social networks}

In terms of the association between parent-child connectedness, communication and parents' involvement in children's lives and CB, research is still ongoing (Cross et al., 2015). Nonetheless, studies indicate that parental monitoring (Low \& Espelage, 2013; Spies Shapiro \& Margolin, 2014) can potentially affect CB levels. Particularly, Khurana, Bleakley, Jordan and Romer (2015) informed that parental monitoring through communication and efforts to regulate specific forms of Internet use were associated with reduced rates of CB. Likewise, Fousiani, Dimitropoulou, Michaelides and Van Petegem (2016) revealed that parental psychological control directly predicts $\mathrm{CB}$, and parental autonomy support is associated with lower levels of $\mathrm{CB}$. However, parental monitoring does not necessarily prevent $\mathrm{CB}$ perpetration (Floros, Siomos, Fisoun, Dafouli \& Geroukalis, 2013).

There is little research on the relationship between parenting style and CB. Authoritative Internet parenting style is the most common, followed by permissive, authoritarian, laissez-faire Internet parenting style, and finally a mixed Internet parenting style, which combines both authoritative and permissive style (Valcke, Bonte, De Wever \& Rots, 2010). Kokkinos, Antoniadou, Asdre and Voulgaridou (2016) found the following order of popularity: democratic, indulgent, neglectful, and last authoritative parenting style. This study also showed that children of democratic parents have significant higher scores in safe Internet use, and are thus more protected from CB. Non-democratic parenting aspects 
including psychological control tend to predict $\mathrm{CB}$; while on the contrary, parental autonomy support decreases the likelihood of CB (Fousiani et al., 2016). Lastly, Leung and Lee (2012) showed a significant and negative bivariate relationship between strictness and internet addiction; meaning that the stricter the parenting and the more involved the style, the lower the likelihood of the adolescent's Internet addiction, and therefore more protection from CB.

Parenting styles change with children's age (Özgür, 2016) towards the laissez-faire approach. Additionally, children today have unlimited access to new technological advances, thus in a way the use of technology comes naturally. On the other hand, parents can struggle to keep up with the latest technological devices, which essentially make it more difficult to understand risk and so protect their children from CB (Cassidy, Brown \& Jackson, 2012). In contrast to SB, there are insufficient studies on the relationship between siblings and $\mathrm{CB}$; Possibly because the phenomenon is extremely low (Tanrikulu \& Campbell, 2015). In general, Knopf (2015) found family connectedness, support and warmth were protective factors.

Literature on $\mathrm{CB}$ in relation to friendship quality, connectedness and communication, is limited (Nilan, Burgess, Hobbs, Threadgold \& Alexander, 2015). Regardless, one study indirectly investigated this association, and reported a statistically significant association between CB victimisation and internalising problems (Aoyama, Saxon \& Fearon, 2011). It also concluded that although peer support moderates victimisation and perpetration behavior in terms of $\mathrm{SB}$, no such association is proven for $\mathrm{CB}$.

\section{Individual characteristics}

As with SB, the association between empathy and CB appeared is well recorded; Ang and Goh (2010) reported that both boys and girls with low affective empathy and low cognitive empathy score higher on $\mathrm{CB}$ than those with high cognitive empathy. Others 
Running head: School-bullying and Cyber-bullying

(Topcu \& Erdur-Baker, 2012) found that the combined effect of affective and cognitive empathy mediates the gender differences in CB. Some articles (Brewer \& Kerslake, 2015; Del Rey, Lazuras, Casas, Barkoukis, Ortega-Ruiz, \& Tsorbatzoudis, 2016) reported that low empathy is a significant individual predictor of $\mathrm{CB}$ perpetration. However, studies found that empathy was not a strong predictor for either CB perpetration or victimisation (Athanasiades, Baldry, Kamariotis, Kostouli and Psalti, 2016). Barlińska, Szuster and Winiewski (2013) found that empathy diminishes the likelihood of negative bystander behavior, and individuals with high affective empathy provide more support to CB victims (Machackova \& Pfetsch, 2016). Finally, some anti-CB strategies that use empathy as a tool for CB reduction report promising results (Schultze- Krumbholz, Schultze, Zagorscak, Wölfer \& Scheithauer, 2016; 2015).

Research on the association between CB and self-esteem revealed that both victims and perpetrators of CB have significantly lower self-esteem than those who have little or no experience with CB (Patchin \& Hinduja, 2010; Cénat, Hébert, Blais, Lavoie, Guerrier \& Derivois, 2014). However, other studies (Robson \& Witenberg, 2013) found no association between self-esteem and CB. Brewer and Kerslake (2015) showed that the combination of loneliness, empathy and self-esteem predicted CB victimisation and perpetration; and indicated that self-esteem is also a significant individual predictor of $\mathrm{CB}$ victimisation and perpetration.

A number of studies have examined the relationship between aggression and involvement in CB has been examined (for example see Casas, Del Rey \& Ortega-Ruiz, 2013; İçellioğlu \& Özden, 2014; Rafferty \& Vander Ven, 2014; Runions \& Bak 2015). Research (Ang et al., 2011; Burton, Florell \& Wygant, 2013) reported a significant and positive association between normative beliefs about aggression and CB. Whereas Pyżalski (2012) reported that $39 \%$ of adolescents electronically attack young people they meet in 
Running head: School-bullying and Cyber-bullying

school or in the place where they live, but not their close friends; $16.9 \%$ would be a former romantic partner; $15.9 \%$ would attack groups of people; boys attacking more frequently groups or ideas; finally, girls attack more often young people they know offline (but not close friends) and former romantic partners. When distinguishing between proactive and reactive aggression in relation to $\mathrm{CB}$, Ang et al. (2014), informed that proactive aggression is positively associated to $\mathrm{CB}$, while reactive aggression and $\mathrm{CB}$ have no significant association.

When compared with SB there has been relatively less research on the association between anger and CB. Lonigro, Schneider, Laghi, Baiocco, Pallini and Brunner (2015) found that the outward, explosive expression of anger appears to be common among cyberbullies. Whereas, Aricak and Ozbay (2016) informed that individual difficulties to identify feelings (alexithymia) such as anger, could explain the increase in CB victimisation and perpetration. A study by Ak et al., 2015 indicated that the inability to appropriately express anger could increase the potential for cyber-victims to subsequently bully others as a form of revenge. There are gender differences; males who direct their anger inward are more likely to become cyber-bullies than females, and males who are victimised online are more likely to express their anger outward.

Impulsivity also appears associated with CB (Fanti, Demetriou \& Hawa, 2012), particularly for males. For example, Workman (2012) suggested that impulsive behaviour is associated with cyber-smearing as a result of limited self-control, and vengefulness. However, impulsivity can often be a temporary characteristic of people when engaging for the first time in cyberspace; particularly, young individuals could behave in a careless and impulsive way when they access cyberspace for the first time (Korenis \& Billick, 2014).

Internet users need self-control to avoid cyber addiction (Catanzaro, 2011). Studies on CB (Vazsonyi, Machackova, Sevcikova, Smahel \& Cerna, 2012) have demonstrated indirect 
Running head: School-bullying and Cyber-bullying

effects of low self-control behaviour; such as for perpetration low self-control shows a moderate effect on offline bullying perpetration, which is linked to CB perpetration, but for victimisation the effect appears weaker. Likewise, Marcum, Higgins, Freiburger and Ricketts (2014) concluded that both males and females with lower levels of self-control are more likely to participate in CB by posting hurtful messages or pictures to Facebook, implying that low self-control is a significant predictor for CB perpetration (Li, Holt, Bossler \& May, 2016; You \& Lim, 2016).

Moral disengagement and CB perpetration are associated (Perren \& GutzwillerHelfenfinger, 2012; Sticca, Ruggieri, Alsaker \& Perren, 2013). Studies (Menesini et al. 2013; Wang, Lei, Liu and $\mathrm{Hu}, 2016$ ) have revealed that adolescents with a high moral disengagement report significantly higher scores of $\mathrm{CB}$ than those with low moral disengagement. Robson and Witenberg (2013) concluded that moral disengagement and the specific practices of diffusion of responsibility and attribution of blame predict CB. Finally, it was advised (Talwar, Gomez-Garibello \& Shariff, 2014; Harrison, 2015) that research on CB and morality or moral values, must be further explored, especially, the aspect of how morals impact upon children's perceptions of CB. In regard to proportioning blame (Weber, Ziegele \& Schnauber, 2013) showed that people frequently attribute more responsibility for a CB incident to the victim when the victim is overly extravert, rather than blaming the bully.

\section{Coping skills}

The association between $\mathrm{CB}$ and coping strategies, is much less researched in comparison to SB. Only one article was identified, and findings suggest that CB victims commonly use reactive coping, preventive coping, and thinking that there is no way to prevent CB (Parris, Varjas, Meyers \& Cutts, 2012; 2011). In terms of reactive techniques, the 
Running head: School-bullying and Cyber-bullying

latter study reported four coping strategies: avoidance, acceptance, justification, and seeking social support.

\section{Relevance of the literature for bullying strategies}

Researchers are focused on risk and preventive factors for both victimisation and perpetration of SB and CB. In terms of factors, literature indicates that generic background factors, environmental, and personality play a role in both SB and CB (Connolly \& Beaver, 2014). However, influential factors regarding SB and CB can be divided into two groups: First, risk factors that cannot be purposively manipulated for anti-bullying strategies, such as: age (Sourander Helstelä, Helenius \& Piha, 2000); gender (Newman, Woodcock \& Dunham, 2006); race/ethnicity (Fox \& Stallworth, 2005); country of origin (Eslea \& Mukhtar, 2000); religion (Dupper, Forrest-Bank \& Lowry-Carusillo, 2015; 2014); sexual orientation (Russell, Day, Ioverno \& Toomey, 2016); disabilities (Vickers, 2009); mental health (Gruber \& Fineran, 2008); and physical health (Kowalski \& Limber, 2013). Second, factors that were concentrated on for the current review, which can be purposively manipulated for anti-bullying strategies use, such as: parent connectedness, style of parenting and monitoring, sibling support, family teasing about appearance, friendship quality, empathy, self-esteem, aggression, anger, impulsivity, self-control, guilt, morality, and coping skills/strategies.

\section{Family and friends}

Parent connectedness and communication can act as both a protective and risk factors for SB and CB. For SB parental overprotectiveness is a risk factor for victimisation, and lack of parental warmth is a risk factor for perpetration (Wienke et al., 2009; 2008). Parents who closely monitor their child's online activity reduce the opportunity for victimisation (Spies et 
al., 2014). However, psychological control can lead to an increase in children engaging in CB victimisation (Fousiani et al., 2016). In general, if parents maintain a supportive close relationship based on communication and healthy monitoring, then the likelihood of engagement in both SB and CB decreases.

This relationship is linked to the parenting style (Van der Watt, 2014). A supportive parenting style reduces victimisation and perpetration for SB (Aslan, 2011; Rajendran, Kruszewski \& Halperin, 2016). Similarly, democratic parenting styles have significantly higher scores for safe Internet use, which protect from CB (Kokkinos et al., 2016). Psychological control and punitive parenting are risk factors for victimisation for both SB and CB (Gómez-Ortiz et al., 2014; Fousiani et al., 2016; Gómez-Ortiz et al., 2016). However, in the case of $\mathrm{CB}$ parental style and control decreases as a child ages, thus increasing risk (Özgür, 2016).

Perhaps surprisingly, the literature on the role of sibling support and bullying is scarce. Studies that do exist suggest that siblings can also act as a protective factor for both SB and CB. Younger children seeking and expecting support from their older siblings when victimised at school; whereas older siblings see the same relationship as a responsibility charged with by parents and in many cases as an unwanted burden (Hadfield et al., 2006). Results appeared similar for both SB and CB, implying that sibling support and family support in general functions as a preventive factor for both forms of bullying (Knopf, 2015). Siblings are not always the source of support, but the source of victimisation as well (Skinner \& Kowalski, 2013); however, limited attention has been paid to this field (Krienert \& Walsh, 2011). On the contrary, CB and sibling teasing/bullying appears unrelated (Tanrikulu \& Campbell, 2015). As a conclusion, it is apparent that future research must pay more attention to sibling bullying, both for SB and CB.

Friendship quality, communication and connectedness have a relationship to SB 
Running head: School-bullying and Cyber-bullying

perpetration and victimisation and can be a protective factor (Bollmer et al., 2005; Kendrick et al., 2012; Woods et al., 2009). Although limited, studies did not find that this was the case for CB (Aoyama et al., 2011; Nilan et al., 2015).

\section{Individual factors}

Empathy is amongst the most well studied factors in relation to SB. It appears that results are more consistent for SB, than $\mathrm{CB}$. Both SB and CB show an association with low empathy, but the affective component appears more associated with SB (Stavrinides et al., 2010). The results indicate that individuals with both components of low empathy engage in more CB; however, they remain inconclusive (Ang \& Goh, 2010; Brewer and Kerslake, 2015; Athanasiades et al., 2016). A possible explanation could be the fact that it would require encountering the victim face to face or witnessing the consequences of victimisation in order to understand the victim's emotions, which is possible at school, but not as feasible in cyberspace. In general low empathy appears associated with perpetration and particularly for males (Jolliffe, \& Farrington, 2011; Topcu \& Erdur-Baker, 2012).

Like empathy, literature on self-esteem as a factor for SB is extensive (Rigby \& Cox, 1996; Brito \& Oliveira, 2013) and diverse (Tsaousis, 2016), presenting self-esteem both as a factor and a consequence of SB (McMahon et al., 2010; Drennan et al., 2011). Again, this association appears stronger for boys than girls (Salmivalli et al., 1999), with bullies exhibiting higher self-esteem than victims (Karatzias et al., 2002). However, both bullies and victims exhibiting lower self-esteem than unengaged individuals in SB (Atik \& Güneri, 2013), and girls only in the pure bully and bully/victim groups exhibiting significant increases in self-esteem over time (Pollastri et al., 2010). Literature shows that both SB and CB have an impact on both victims' and perpetrators' self-esteem, but self-esteem as a factor is clearly influential for SB while for CB findings are more incongruent. 
Running head: School-bullying and Cyber-bullying

Aggression is also one of the main risk factors for SB perpetration (Thornton et al., 2013). Particularly, reporting physical aggression for boys, and verbal aggression for girls (Craig, 1998). Those who examined aggression in terms of proactive and reactive aggression reported that both proactive and reactive aggressiveness are related to SB perpetration, with proactive having the lead in this association (Roland \& Idsoe, 2001). Only proactive aggression seemed associated to CB (Ang et al., 2014). Therefore, the conclusion is that there are similarities between SB and CB in terms of aggression, particularly regarding proactive aggression. If an individual is determined to initiate events that exhibit aggressive behaviour, then inevitably he/she will be involved in $\mathrm{SB}$ or $\mathrm{CB}$, depending where the proactive aggressive behaviour is taking place.

Anger is also a strong predictor of perpetration of SB and CB (Tanrikulu \& Campbell, 2015), and as a predecessor of aggression (Ramírez \& Andreu, 2006). Specifically, for males the higher the anger levels the higher the likelihood of perpetration (Bosworth et al., 1999), and victimisation (Rieffe et al., 2012). There are fewer studies on anger and CB; nonetheless, $\mathrm{CB}$ victimisation is positively associated with anger when expressed, and particularly for males associated with CB perpetration when internalised (Ak et al., 2015). Explosive expression of anger (Lonigro et al., 2015) and alexithymia of anger (Aricak \& Ozbay, 2016) are commonly found in CB bullies.

Another common finding in the literature is the relationship between impulsivity and SB perpetration (Oluyinka, 2008) and victimisation (Jolliffe \& Farrington, 2011) and CB (Fanti et al., 2012), particularly for males. Explanations differ, some authors (Workman, 2012) suggest that impulsivity is a result of low self-control, and others found it to be a temporary characteristic for the-first-time Internet users and those seeking revenge (Korenis \& Billick, 2014). Low self-control is also associated to SB perpetration (Moon \& Alarid, 2015), and in a limited sample of children with ADHD victimisation (Unnever \& Cornell, 
Running head: School-bullying and Cyber-bullying

2003). Low self-control can have both indirect (Vazsonyi et al., 2012) and direct (Marcum et al., 2014; You \& Lim, 2016) effects on CB.

Low guilt is associated with SB perpetration (Menesini \& Camodeca, 2008), bullyvictims are more guilt-prone compared to bullies (Ahmed \& Braithwaite, 2012), and guilt increases with age (Olthof, 2012). Perhaps age mediates this relationship and thus we see SB bullying decreasing with age. On the contrary, literature on guilt and CB is scarce, clearly indicating a gap in research; nonetheless, a high level of moral disengagement is significantly associated with CB perpetration (Wang et al., 2016), thus implying that since guilt is among the moral emotions, then low guilt would be associated to CB perpetration. However, it must be acknowledged that guilt comes with witnessing consequences; experiencing guilt because of $\mathrm{CB}$ perpetration is not always feasible.

Moral disengagement is associated with both forms of bullying (Sims-Schouten, 2015), but more research is needed for CB. In regard to SB, findings showed that bullies and bully-victims exhibit higher moral disengagement than non-involved in bullying children (Obermann, 2011). In addition, a lack of moral values and remorse predict both SB and CB (Perren \& Gutzwiller-Helfenfinger, 2012). Although the need for further research has been identified, moral disengagement and CB perpetration appear to be positively associated (Sticca et al., 2013).

\section{Coping Strategies}

Coping strategies, including minimisation, are directly relevant to interventions. However, research has found that although that problem-solving strategies protect young people from bullying, emotionally oriented coping strategies put young students at higher risk for victimization (Baldry \& Farrington, 2005). Gender differences have again been found (Garnett et al., 2015), with boys using externalising strategies with greater frequency than girls, and girls seeking social support more often than boys. It should be noted that individual 
Running head: School-bullying and Cyber-bullying

confounding variables, such as personality type can impact on the effectiveness of coping strategies and associated interventions (Trémolière \& Djeriouat, 2016).

Only one article was found on CB (Parris et al., 2012; 2011); which informs that CB victims commonly use reactive coping, preventive coping, and thinking that there is no way to prevent $\mathrm{CB}$, while indicates that these strategies rarely benefit victims. As a conclusion, more research is needed for $\mathrm{CB}$ in order to see if the same factor relates similarly to $\mathrm{CB}$ as to SB. Nonetheless, the assumption is that minimising a hurtful even as a perpetrator must be much easier in $\mathrm{CB}$ events than SB evens, since perpetrators do not have to encounter the consequences of their actions in a real-life environment.

\section{Discussion}

As a general comment and noteworthy observation about previous literature and findings, are the contradictions and conflicting results found amongst the studies included in this review. The most logical reason for the conflicting results is probably the definition of bullying. Hellstrom et al (2015) informed that there is differentiation between adolescents' and researchers' understanding of the definition of bullying; as a consequence this differentiation in perception often leads to inconsistencies or contradictions in research (Cowan, 2012). Therefore, taking into account the number of examined studies, the differentiation between samples used for each study, the variation of the definition and perception of bullying used in each study; variation of the term bullying (including SB \& CB) between researchers and participants; provides a deeper understanding of why results appear contradictory.

\section{Limitations}


Running head: School-bullying and Cyber-bullying

Some limitations of the present review must be acknowledged, starting with the fact that it would be impossible to include findings from all previous empirical projects in one single paper that describes all dynamic risk factors. It is recommended that fellow researchers use this paper mainly as a direction for focusing in their area of interest related to SB and SB, including the examined factors. This review examines factors that are most commonly mentioned in literature; it is likely that factors not examined in this study, are associated to $\mathrm{SB}$, and likewise to $\mathrm{CB}$ in a similar manner. In addition, factors such as age, gender, and in general background factors were not included in this review, simply because such factors cannot be altered or manipulated. In the case that background factors present a strong effect on $\mathrm{SB}$ and/or $\mathrm{CB}$, anti-bullying methodologies must flexible to accommodate age range or gender. Although, excluding confounding or static factors from this review presents a limitation, nonetheless, their exclusion serves also as strength for this study because it focuses on factors that researchers can use for interventions.

Methodological information (e.g. sample characteristics, background characteristics, tools and scales used for these studies etc.) of the examined works were excluded from this review. The main aim was to present a general summative aggregative and informative picture of the associated to SB and CB factors, rather than focusing on the methodological details related to each study.

\section{Conclusion}

This article provides a direction and a summative picture of research regarding SB, $\mathrm{CB}$, and related factors, while also indicating important gaps in previous research. The review can inform those developing anti-bullying strategies to gain a first understanding of which factors relate to SB and to $\mathrm{CB}$. In addition, by identifying research gaps this study presents the opportunity to fellow researchers to focus on their area of interest that contain 
Running head: School-bullying and Cyber-bullying

the gap and assist in understanding and dealing with SB and CB. This review can be thought of as a compass for fellow researchers and particularly those new to the field, which provides an aggregative picture of the differences between SB and CB in terms of risk and preventive factors.

\section{References}

Agatston, P. W., Kowalski, R., \& Limber, S. (2007). Students' perspectives on cyber bullying. Journal of Adolescent Health, 41(6), S59-S60. doi:10.1016/j.jadohealth.2007.09.003.

Ahmed, E., \& Braithwaite, V. (2004). "what, me ashamed?" shame management and school bullying. Journal of Research in Crime and Delinquency, 41(3), 269-294. doi:10.1177/0022427804266547.

Ahmed, E., \& Braithwaite, V. (2012). Learning to manage shame in school bullying: Lessons for restorative justice interventions. Critical Criminology, 20(1), 79-97. doi:10.1007/s10612-011-9151-y.

Ak, S., Ozdemir, Y., \& Kuzucu, Y. (2015). Cybervictimization and cyberbullying: The mediating role of anger, don't anger me. Computers in Human Behavior, 49, 437. doi:10.1016/j.chb.2015.03.030.

Ang, R. P., \& Goh, D. H. (2010). Cyberbullying among adolescents: The role of affective and cognitive empathy, and gender. Child Psychiatry and Human Development, 41(4), 387-397. doi:10.1007/s10578-010-0176-3.

Ang, R. P., Huan, V. S., \& Florell, D. (2014). Understanding the relationship between proactive and reactive aggression, and cyberbullying across united states and singapore adolescent samples. Journal of Interpersonal Violence, 29(2), 237-254. doi:10.1177/0886260513505149. 
Running head: School-bullying and Cyber-bullying

Ang, R. P., Tan, K., \& Talib Mansor, A. (2011). Normative beliefs about aggression as a mediator of narcissistic exploitativeness and cyberbullying. Journal of Interpersonal Violence, 26(13), 2619-2634. doi:10.1177/0886260510388286.

Ansary, N. S., Elias, M. J., Greene, M. B., \& Green, S. (2015). Best practices to address (or reduce) bullying in schools. Phi Delta Kappan, 97(2), 30.

Antoniadou, N., \& Kokkinos, C. M. (2015;2013;). A review of research on cyber-bullying in Greece. International Journal of Adolescence and Youth, 20(2), 185-17. doi:10.1080/02673843.2013.778207.

Aoki, T., Miyashita, M., Inoko, K., Kodaira, K., \& Osawa, M. (2010). P01-170 - bullying and depression among children. European Psychiatry, 25, 379-379. doi:10.1016/S09249338(10)70376-X.

Aoyama, I., Saxon, T. F., \& Fearon, D. D. (2011). Internalizing problems among cyberbullying victims and moderator effects of friendship quality. Multicultural Education \& Technology Journal, 5(2), 92-105. doi:10.1108/17504971111142637.

Archer, J., \& Southall, N. (2009). Does cost-benefit analysis or self-control predict involvement in bullying behavior by male prisoners? Aggressive Behavior, 35(1), 3140. doi:10.1002/ab.20283.

Aricak, O. T., \& Ozbay, A. (2016). Investigation of the relationship between cyberbullying, cybervictimization, alexithymia and anger expression styles among adolescents. Computers in Human Behavior, 55, 278-285. doi:10.1016/j.chb.2015.09.015.

Asencio, E. K. (2013). Self-esteem, reflected appraisals, and self-views: Examining criminal and worker identities. Social Psychology Quarterly, 76(4), 291-313. doi:10.1177/0190272513504222. 
Running head: School-bullying and Cyber-bullying

Aslan, S. (2011). The analysis of relationship between school bullying, perceived parenting styles and self-esteem in adolescents. Procedia - Social and Behavioral Sciences, 30, 1798-1800. doi:10.1016/j.sbspro.2011.10.346.

Athanasiades, C., Baldry, A. C., Kamariotis, T., Kostouli, M., \& Psalti, A. (2016). The "net" of the internet: Risk factors for cyberbullying among secondary-school students in greece. European Journal on Criminal Policy and Research, 22(2), 301-317. doi:10.1007/s10610-016-9303-4.

Atik, G., \& Güneri, O. Y. (2013). Bullying and victimization: Predictive role of individual, parental, and academic factors. School Psychology International, 34(6), 658-673.

Baldry, A. C., \& Farrington, D. P. (2005). Protective factors as moderators of risk factors in adolescence bullying. Social Psychology of Education, 8(3), 263-284. doi:10.1007/s11218-005-5866-5.

Ball, H. A., Arseneault, L., Taylor, A., Maughan, B., Caspi, A., \& Moffit, T. E. (2008). Genetic and environmental influences on victims, bullies and bully-victims in childhood. Journal of Child Psychology and Psychiatry, 49(1), 104-112. doi:10.1111/j.1469-7610.2007.01821.x.

Barlińska, J., Szuster, A., \& Winiewski, M. (2013). Cyberbullying among adolescent bystanders: Role of the communication medium, form of violence, and empathy. Journal of Community \& Applied Social Psychology, 23(1), 37-51. doi:10.1002/casp.2137.

Bauman, S., \& Baldasare, A. (2015). Cyber aggression among college students: Demographic differences, predictors of distress, and the role of the university. Journal of College Student Development, 56(4), 317-330. 
Running head: School-bullying and Cyber-bullying

Bauman, S., \& Newman, M. L. (2013). Testing assumptions about cyberbullying: Perceived distress associated with acts of conventional and cyber bullying. Psychology of Violence, 3(1), 27-38. doi:10.1037/a0029867.

Beckman, L., Hagquist, C., Hellstrom, L., Karlstads universitet, Fakulteten för humaniora och samhällsvetenskap (from 2013), \& Centrum för forskning om barns och ungdomars psykiska hälsa. (2013). Discrepant gender patterns for cyberbullying and traditional bullying - an analysis of swedish adolescent data. Computers in Human Behavior, 29(5), 1896. doi:10.1016/j.chb.2013.03.010.

Bennett, T., Holloway, K., \& Farrington, D. (2008). The statistical association between drug misuse and crime: A meta-analysis. Aggression and Violent Behavior, 13(2), 107-118. doi:10.1016/j.avb.2008.02.001.

Bertolotti, T., \& Magnani, L. (2013). A philosophical and evolutionary approach to cyberbullying: Social networks and the disruption of sub-moralities. Ethics and Information Technology, 15(4), 285-299. doi:10.1007/s10676-013-9324-3.

Besag, V. E. (1989). Bullies and victims in schools. A guide to understanding and management. England: Open University Press.

Bollmer, J. M., Milich, R., Harris, M. J., \& Maras, M. A. (2005). A friend in need: The role of friendship quality as a protective factor in peer victimization and bullying. Journal of Interpersonal Violence, 20(6), 701-712. doi:10.1177/0886260504272897.

Borowsky, I. W., Taliaferro, L. A., \& McMorris, B. J. (2013). Suicidal thinking and behavior among youth involved in verbal and social bullying: Risk and protective factors. The Journal of Adolescent Health : Official Publication of the Society for Adolescent Medicine, 53(1 Suppl), S4. doi:10.1016/j.jadohealth.2012.10.280. 
Running head: School-bullying and Cyber-bullying

Bosworth, K., Espelage, D. L., \& Simon, T. R. (1999). Factors associated with bullying behavior in middle school students. The Journal of Early Adolescence, 19(3), 341362. doi:10.1177/0272431699019003003.

Boulton, M. J., Hardcastle, K., Down, J., Fowles, J., \& Simmonds, J. A. (2014). A comparison of preservice teachers' responses to cyber versus traditional bullying scenarios: Similarities and differences and implications for practice. Journal of Teacher Education, 65(2), 145-155. doi:10.1177/0022487113511496.

Bourke, S., \& Burgman, I. (2010). Coping with bullying in australian schools: How children with disabilities experience support from friends, parents and teachers. Disability \& Society, 25(3), 359-371. doi:10.1080/09687591003701264.

Bowes, L., Maughan, B., Caspi, A., Moffitt, T. E., \& Arseneault, L. (2010). Families promote emotional and behavioural resilience to bullying: Evidence of an environmental effect. Journal of Child Psychology and Psychiatry, and Allied Disciplines, 51(7), 809. doi:10.1111/j.1469-7610.2010.02216.x.

Brewer, G., \& Kerslake, J. (2015). Cyberbullying, self-esteem, empathy and loneliness. Computers in Human Behavior, 48, 255-260. doi:10.1016/j.chb.2015.01.073.

Brito, C. C., \& Oliveira, M. T. (2013). Bullying and self-esteem in adolescents from public schools. Jornal De Pediatria, 89(6), 601-607. doi:10.1016/j.jped.2013.04.001.

Burton, K. A., Florell, D., \& Wygant, D. B. (2013). The role of peer attachment and normative beliefs about aggression on traditional bullying and cyberbullying: Peer attachment, aggression, and cyberbullying. Psychology in the Schools, 50(2), 103115. doi:10.1002/pits.21663.

Cambell, M.A., Spears, B., Slee, P., Kift, S., \& Butler, D. (2011, April). 'The prevalence of cyberbullying in Australia'. 5th World conference and IV Iberoamerican congress on 
Running head: School-bullying and Cyber-bullying

violence in school. Investigations, interventions, evaluations and public policies Mendoza, Argentina.

Cankaya, I. H., \& Tan, C. (2011). Effect of cyber bullying on the distrust levels of preservice teachers: Considering internet addiction as a mediating variable. Procedia Computer Science, 3, 1353-1360. doi:10.1016/j.procs.2011.01.015.

Caravita, S. C. S., Gini, G., \& Pozzoli, T. (2012). Main and moderated effects of moral cognition and status on bullying and defending: Morality and bullying: Moderations by status. Aggressive Behavior, 38(6), 456-468. doi:10.1002/ab.21447.

Carbone-Lopez, K., Esbensen, F., \& Brick, B. T. (2010). Correlates and consequences of peer victimization: Gender differences in direct and indirect forms of bullying. Youth Violence and Juvenile Justice, 8(4), 332-350. doi:10.1177/1541204010362954.

Casas, J. A., Del Rey, R., \& Ortega-Ruiz, R. (2013). Bullying and cyberbullying: Convergent and divergent predictor variables. Computers in Human Behavior, 29(3), 580-587. doi:10.1016/j.chb.2012.11.015.

Cassidy, W., Brown, K., \& Jackson, M. (2012). “Making kind cool”: Parents' suggestions for preventing cyber bullying and fostering cyber kindness. Journal of Educational Computing Research, 46(4), 415-436. doi:10.2190/EC.46.4.f.

Cassidy, W., Jackson, M., \& Brown, K. N. (2009). Sticks and stones can break my bones, but how can pixels hurt me?: Students' experiences with cyber-bullying. School Psychology International, 30(4), 383-402. doi:10.1177/0143034309106948.

Catanzaro, M. F. (2011). Indirect aggression, bullying and female teen victimization: A literature review. Pastoral Care in Education, 29(2), 83-101. doi:10.1080/02643944.2011.573495. 
Running head: School-bullying and Cyber-bullying

Cénat, J. M., Blais, M., Hébert, M., Lavoie, F., \& Guerrier, M. (2015). Correlates of bullying in quebec high school students: The vulnerability of sexual-minority youth. Journal of Affective Disorders, 183, 315.

Cénat, J. M., Hébert, M., Blais, M., Lavoie, F., Guerrier, M., \& Derivois, D. (2014). Cyberbullying, psychological distress and self-esteem among youth in quebec schools. Journal of Affective Disorders, 169, 7-9. doi:10.1016/j.jad.2014.07.019.

Cesaroni, C., Downing, S., \& Alvi, S. (2012). Bullying enters the 21st century? turning a critical eye to cyber-bullying research. Youth Justice, 12(3), 199-211. doi:10.1177/1473225412459837.

Chang, F., Lee, C., Chiu, C., Hsi, W., Huang, T., \& Pan, Y. (2013). Relationships among cyberbullying, school bullying, and mental health in Taiwanese adolescents. Journal of School Health, 83(6), 454-462. doi:10.1111/josh.12050.

Chen, V. H. H., \& Chng, G. S. (2016). Active and restrictive parental mediation over time: Effects on youths' self-regulatory competencies and impulsivity. Computers \& Education, 98, 206-212. doi:10.1016/j.compedu.2016.03.012.

Chui, W. H., \& Chan, H. C. O. (2013). Association between self-control and school bullying behaviors among macanese adolescents. Child Abuse \& Neglect, 37(4), 237-242. doi:10.1016/j.chiabu.2012.12.003.

Chui, W. H., \& Chan, H. C. O. (2015;2014;). Self-control, school bullying perpetration, and victimization among macanese adolescents. Journal of Child and Family Studies, 24(6), 1751-1761. doi:10.1007/s10826-014-9979-3.

Ciucci, E., \& Baroncel A. (2014). The emotional core of bullying: Further evidences of the role of callous-unemotional traits and empathy. Personality and Individual Differences, 67, 69-74. doi:10.1016/j.paid.2013.09.033. 
Running head: School-bullying and Cyber-bullying

Cluver, L., Bowes, L., \& Gardner, F. (2010). Risk and protective factors for bullying victimization among AIDS-affected and vulnerable children in South Africa. Child Abuse \& Neglect, 34(10), 793-803. doi:10.1016/j.chiabu.2010.04.002.

Conners-Burrow, N. A., Johnson, D. L., Whiteside-Mansell, L., Mckelvey, L., \& Gargus, R. A. (2009). Adults matter: Protecting children from the negative impacts of bullying. Psychology in the Schools, 46(7), 593-604. doi:10.1002/pits.20400.

Connolly, E. J., \& Beaver, K. M. (2014). Considering the genetic and environmental overlap between bullying victimization, delinquency, and symptoms of Depression/Anxiety. Journal of Interpersonal Violence. doi:10.1177/0886260514564158.

Cowan, R. L. (2012). It's complicated: Defining workplace bullying from the human resource professional's perspective. Management Communication Quarterly, 26(3), 377-403. doi:10.1177/0893318912439474.

Craig, W. M. (1998). The relationship among bullying, victimization, depression, anxiety, and aggression in elementary school children. Personality and Individual Differences, 24(1), 123-130. doi:10.1016/S0191-8869(97)00145-1.

Crapanzano, A. M., Frick, P. J., Childs, K., \& Terranova, A. M. (2011). Gender differences in the assessment, stability, and correlates to bullying roles in middle school children: Gender and bullying. Behavioral Sciences \& the Law, , n/a. doi:10.1002/bsl.1000.

Cross, D., \& Barnes, A. (2014). Using systems theory to understand and respond to family influences on children's bullying behavior: Friendly schools friendly families program. Theory into Practice, 53(4), 293-299. doi:10.1080/00405841.2014.947223.

Cross, D., Lester, L., \& Barnes, A. (2015). A longitudinal study of the social and emotional predictors and consequences of cyber and traditional bullying victimisation. International Journal of Public Health, 60(2), 207-217. doi:10.1007/s00038-0150655-1. 
Running head: School-bullying and Cyber-bullying

David-Ferdon, C., \& Hertz, M. F. (2007). Electronic media, violence, and adolescents: An emerging public health problem. Journal of Adolescent Health, 41(6), S1-S5. doi:10.1016/j.jadohealth.2007.08.020.

Dearden, J. (2004). Resilience: A study of risk and protective factors from the perspective of young people with experience of local authority care. Support for Learning, 19(4), 187-193. doi:10.1111/j.0268-2141.2004.00346.x.

Del Rey, R., Lazuras, L., Casas, J. A., Barkoukis, V., Ortega-Ruiz, R., \& Tsorbatzoudis, H. (2016). Does empathy predict (cyber) bullying perpetration, and how do age, gender and nationality affect this relationship? Learning and Individual Differences, 45, 275281. doi:10.1016/j.lindif.2015.11.021.

DePaolis, K., \& Williford, A. (2015). The nature and prevalence of cyber victimization among elementary school children. Child \& Youth Care Forum, 44(3), 377-393. doi:10.1007/s10566-014-9292-8.

Drennan, J., Brown, M. R., \& Sullivan Mort, G. (2011). Phone bullying: Impact on selfesteem and well-being. Young Consumers, 12(4), 295-309. doi:10.1108/17473611111185850.

Duong, J., \& Bradshaw, C. (2014). Associations between bullying and engaging in aggressive and suicidal behaviors among sexual minority youth: The moderating role of connectedness. Journal of School Health, 84(10), 636-645. doi:10.1111/josh.12196.

Dupper, D. R., Forrest-Bank, S., \& Lowry-Carusillo, A. (2015;2014;). Experiences of religious minorities in public school settings: Findings from focus groups involving muslim, jewish, catholic, and unitarian universalist youths. Children \& Schools, 37(1), 37-45. doi:10.1093/cs/cdu029. 
Running head: School-bullying and Cyber-bullying

Egan, S. K., \& Perry, D. G. (1998). Does low self-regard invite victimization? Developmental Psychology, 34(2), 299-309. doi:10.1037/0012-1649.34.2.299.

Einolf, C. J. (2012). Is cognitive empathy more important than affective empathy? A response to "Who helps Natural- Disaster victims?". Analyses of Social Issues and Public Policy, 12(1), 268-271. doi:10.1111/j.1530-2415.2012.01281.x.

Erreygers, S., Pabian, S., Vandebosch, H., \& Baillien, E. (2016). Helping behavior among adolescent bystanders of cyberbullying: The role of impulsivity. Learning and Individual Differences, 48, 61-67. doi:10.1016/j.lindif.2016.03.003.

Eslea, M., \& Mukhtar, K. (2000). Bullying and racism among asian schoolchildren in britain. Educational Research, 42(2), 207-217. doi:10.1080/001318800363845.

Espelage, D. L., Bosworth, K., \& Simon, T. R. (2001). Short-term stability and prospective correlates of bullying in middle-school students: An examination of potential demographic, psychosocial, and environmental influences. Violence and Victims, $16(4), 411$.

Espelage, D., Green, H., \& Polanin, J. (2012). Willingness to intervene in bullying episodes among middle school students: Individual and peer-group influences. The Journal of Early Adolescence, 32(6), 776-801.

Fanti, K. A., \& Henrich, C. C. (2015). Effects of self-esteem and narcissism on bullying and victimization during early adolescence. The Journal of Early Adolescence, 35(1), 529. doi: $10.1177 / 0272431613519498$.

Fanti, K. A., \& Kimonis, E. R. (2012). Bullying and victimization: The role of conduct problems and psychopathic traits. Journal of Research on Adolescence, 22(4), 617631. doi:10.1111/j.1532-7795.2012.00809.x. 
Running head: School-bullying and Cyber-bullying

Fanti, K. A., Demetriou, A. G., \& Hawa, V. V. (2012). A longitudinal study of cyberbullying: Examining risk and protective factors. European Journal of Developmental Psychology, 9(2), 168. doi:10.1080/17405629.2011.643169.

Farrington, D. P., \& Baldry, A. C. (2010). Individual risk factors for school bullying. Journal of Aggression, Conflict and Peace Research, 2(1), 4-16. doi:10.5042/jacpr.2010.0001.

Finkelhor, D., Turner, H. A., \& Hamby, S. (2012). Let's prevent peer victimization, not just bullying. Child Abuse and Neglect, 36(4), 271-274. doi:10.1016/j.chiabu.2011.12.001.

Fleming, L. C., \& Jacobsen, K. H. (2009). Bullying and symptoms of depression in Chilean middle school students. Journal of School Health, 79(3), 130-137. doi:10.1111/j.1746-1561.2008.0397.x.

Floros, G. D., Siomos, K. E., Fisoun, V., Dafouli, E., \& Geroukalis, D. (2013). Adolescent online cyberbullying in greece: The impact of parental online security practices, bonding, and online impulsiveness. Journal of School Health, 83(6), 445-453. doi:10.1111/josh.12049.

Fousiani, K., Dimitropoulou, P., Michaelides, M. P., \& Van Petegem, S. (2016). Perceived parenting and adolescent cyber-bullying: Examining the intervening role of autonomy and relatedness need satisfaction, empathic concern and recognition of humanness. Journal of Child and Family Studies, 25(7), 2120-2129. doi:10.1007/s10826-0160401-1.

Fox, C. L., \& Farrow, C. V. (2009). Global and physical self-esteem and body dissatisfaction as mediators of the relationship between weight status and being a victim of bullying. Journal of Adolescence, 32(5), 1287-1301. doi:10.1016/j.adolescence.2008.12.006.

Fox, S., \& Stallworth, L. E. (2005). Racial/ethnic bullying: Exploring links between bullying and racism in the US workplace. Journal of Vocational Behavior, 66(3), 438-456. doi:10.1016/j.jvb.2004.01.002. 
Running head: School-bullying and Cyber-bullying

Frisen, A., Hasselblad, T., Holmqvist, K., Department of Psychology, Psykologiska institutionen, Samhällsvetenskapliga fakulteten. . Göteborgs universitet. (2012). What actually makes bullying stop? reports from former victims. Journal of Adolescence, 35(4), 981-990. doi:10.1016/j.adolescence.2012.02.001.

Garandeau, C. F., Vartio, A., Poskiparta, E., \& Salmivalli, C. (2016). School bullies' intention to change behavior following teacher interventions: Effects of empathy arousal, condemning of bullying, and blaming of the perpetrator. Prevention Science, doi:10.1007/s11121-016-0712-x.

Garnett, B. R., Masyn, K. E., Austin, S. B., Williams, D. R., \& Viswanath, K. (2015). Coping styles of adolescents experiencing multiple forms of discrimination and bullying: Evidence from a sample of ethnically diverse urban youth. Journal of School Health, 85(2), 109-117. doi:10.1111/josh.12225.

Gerler, E. (2008). bullying. Journal of School Violence, 7(2), 1-2. doi:10.1300/J202v07n02_01.

Goldsmid, S., \& Howie, P. (2014). Bullying by definition: An examination of definitional components of bullying. Emotional and Behavioural Difficulties, 19(2), 210-225. doi:10.1080/13632752.2013.844414.

Gómez-Ortiz, O., Del Rey, R., Casas, J., \& Ortega-Ruiz, R. (2014). Parenting styles and bullying involvement / estilos parentales e implicación en bullying. Cultura y Educación, 26(1), 132-158. doi:10.1080/11356405.2014.908665.

Gómez-Ortiz, O., Romera, E. M., \& Ortega-Ruiz, R. (2016). Parenting styles and bullying. the mediating role of parental psychological aggression and physical punishment. Child Abuse \& Neglect, 51, 132-143. doi:10.1016/j.chiabu.2015.10.025. 
Running head: School-bullying and Cyber-bullying

Gresham, D., Melvin, G. A., \& Gullone, E. (2016). The role of anger in the relationship between internalising symptoms and aggression in adolescents. Journal of Child and Family Studies, 25(9), 2674-2682. doi:10.1007/s10826-016-0435-4.

Gruber, J. E., \& Fineran, S. (2008). Comparing the impact of bullying and sexual harassment victimization on the mental and physical health of adolescents. Sex Roles, 59(1), 1-13. doi:10.1007/s11199-008-9431-5.

Hadfield, L., Edwards, R., \& Mauthner, M. (2006). Brothers and sisters: A source of support for children in school? Education 3-13, 34(1), 65-72. doi:10.1080/03004270500507602.

Harrison, T. (2015). Virtuous reality: Moral theory and research into cyber-bullying. Ethics and Information Technology, 17(4), 275-283. doi:10.1007/s10676-015-9382-9.

Heiman, T., \& Olenik-Shemesh, D. (2015). Cyberbullying experience and gender differences among adolescents in different educational settings. Journal of Learning Disabilities, $48(2), 146-155$.

Hein, V., Koka, A., \& Hagger, M. S. (2015). Relationships between perceived teachers' controlling behaviour, psychological need thwarting, anger and bullying behaviour in high-school students. Journal of Adolescence, 42, 103-114. doi:10.1016/j.adolescence.2015.04.003.

Hellstrom, L., Persson, L., Hagquist, C., Karlstads universitet, Centrum for forskning om barns och ungdomars psykiska halsa, Fakulteten for humaniora och samhallsvetenskap (from 2013). Institutionen för hälsovetenskaper. (2015). Understanding and defining bullying - adolescents' own views. Archives of Public Health, 73(4).

Hemphill, S. A., Kotevski, A., \& Heerde, J. A. (2015). Longitudinal associations between cyber-bullying perpetration and victimization and problem behavior and mental health 
Running head: School-bullying and Cyber-bullying

problems in young australians. International Journal of Public Health, 60(2), 227237. doi:10.1007/s00038-014-0644-9.

Hemphill, S. A., Kotevski, A., Tollit, M., Smith, R., Herrenkohl, T. I., Toumbourou, J. W., \& Catalano, R. F. (2012). Longitudinal predictors of cyber and traditional bullying perpetration in Australian secondary school students. Journal of Adolescent Health, 51(1), 59-65. doi:10.1016/j.jadohealth.2011.11.019.

Hemphill, S. A., Tollit, M., \& Herrenkohl, T. I. (2014). Protective factors against the impact of school bullying perpetration and victimization on young adult externalizing and internalizing problems. Journal of School Violence, 13(1), 125-145. doi:10.1080/15388220.2013.844072.

Hemphill, S. A., Tollit, M., Kotevski, A., \& Heerde, J. A. (2015). Predictors of traditional and cyber-bullying victimization: A longitudinal study of Australian secondary school students. Journal of Interpersonal Violence, 30(15), 2567-2590. doi:10.1177/0886260514553636.

Hinduja, S., \& Patchin, J. W. (2008). Bullying beyond the schoolyard: Preventing and responding to cyberbullying. Thousand Oaks, CA: Corwin Press.

Hoertel, N., Le Strat, Y., Lavaud, P., \& Limosin, F. (2012). Gender effects in bullying: Results from a national sample. Psychiatry Research, 200(2-3), 921-927. doi:10.1016/j.psychres.2012.03.036.

Hoetger, L. A., Hazen, K. P., \& Brank, E. M. (2015). All in the family: A retrospective study comparing sibling bullying and peer bullying. Journal of Family Violence, 30(1), 103111. doi:10.1007/s10896-014-9651-0.

Holland, D., Ireland, J. L., \& Muncer, S. (2009). Impulsivity, attribution and prison bullying: Bully-category and perpetrator-victim mutuality. International Journal of Law and Psychiatry, 32(2), 84-91. doi:10.1016/j.ijlp.2009.01.004. 
Running head: School-bullying and Cyber-bullying

Holt, M. K., Kaufman Kantor, G., \& Finkelhor, D. (2009). Parent/Child concordance about bullying involvement and family characteristics related to bullying and peer victimization. Journal of School Violence, 8(1), 42-63. doi:10.1080/15388220802067813.

Homel, J. B. (2013). Does bullying others at school lead to adult aggression?: The roles of drinking and university participation during the transition to adulthood. Australian Journal of Psychology, 65(2), 98.

Hooge, d., I.E, Nelissen, R. M. A., Breugelmans, S. M., \& Zeelenberg, M. (2011). What is moral about guilt? acting 'prosocially' at the disadvantage of others. Journal of Personality and Social Psychology, 100(3), 462-473.

Hopkins, L., Taylor, L., Bowen, E., \& Wood, C. (2013). A qualitative study investigating adolescents' understanding of aggression, bullying and violence. Children and Youth Services Review, 35(4), 685-693. doi:10.1016/j.childyouth.2013.01.012.

Horton, P., Linköpings universitet, Institutionen för tema, Tema Barn, \& Filosofiska fakulteten. (2011). School bullying and social and moral orders. Children \& Society, 25(4), 268-277. doi:10.1111/j.1099-0860.2011.00377.x.

Huang, Y., \& Chou, C. (2010). An analysis of multiple factors of cyberbullying among junior high school students in Taiwan. Computers in Human Behavior, 26(6), 1581-1590. doi:10.1016/j.chb.2010.06.005.

Hunt, C. (2015). Understanding and combating School-Based bullying from an IndividualLevel perspective: A review. Australian Psychologist, 50(3), 182-185. doi:10.1111/ap.12093.

Hunter, S. C., \& Boyle, J. M. E. (2004). Appraisal and coping strategy use in victims of school bullying. The British Journal of Educational Psychology, 74(Pt 1), 83-107. doi:10.1348/000709904322848833. 
Running head: School-bullying and Cyber-bullying

Hymel, S., \& Bonanno, R. A. (2014). Moral disengagement processes in bullying. Theory into Practice, 53(4), 278-285. doi:10.1080/00405841.2014.947219.

İçellioğlu, S., \& Özden, M. S. (2014). Cyberbullying: A new kind of peer bullying through online technology and its relationship with aggression and social anxiety. Procedia - Social and Behavioral Sciences, 116, 4241-4245. doi:10.1016/j.sbspro.2014.01.924.

Ireland, J. L., \& Archer, J. (2004). Association between measures of aggression and bullying among juvenile and young offenders. Aggressive Behavior, 30(1), 29-42. doi:10.1002/ab.20007.

Jankauskiene, R., Kardelis, K., Sukys, S., \& Kardeliene, L. (2008). Associations between school bullying and psychosocial factors. Social Behavior and Personality, 36(2), 145.

Jantzer, A. M., Hoover, J. H., \& Narloch, R. (2006). The relationship between school-aged bullying and trust, shyness and quality of friendships in young adulthood: A preliminary research note. School Psychology International, 27(2), 146-156. doi:10.1177/0143034306064546

Jolliffe, D., \& Farrington, D. P. (2006). Examining the relationship between low empathy and bullying. Aggressive Behavior, 32(6), 540-550. doi:10.1002/ab.20154.

Jolliffe, D., \& Farrington, D. P. (2011). Is low empathy related to bullying after controlling for individual and social background variables? Journal of Adolescence, 34(1), 59-71. doi:10.1016/j.adolescence.2010.02.001.

Jose, P. E., Kljakovic, M., Scheib, E., \& Notter, O. (2012). The joint development of traditional bullying and victimization with cyber bullying and victimization in adolescence. Journal of Research on Adolescence, 22(2), 301-309. doi:10.1111/j.1532-7795.2011.00764.x. 
Running head: School-bullying and Cyber-bullying

Juvonen, J., \& Gross, E. F. (2008). Extending the school grounds?-Bullying experiences in cyberspace. Journal of School Health, 78(9), 496-505. doi:10.1111/j.17461561.2008.00335.x.

Kaltiala-Heino, R., \& Frojd. (2011). Correlation between bullying and clinical depression in adolescent patients. Adolescent Health, Medicine and Therapeutics, 2011, 37-44. doi:10.2147/AHMT.S11554.

Karatzias, A., Power, K. G., \& Swanson, V. (2002). Bullying and victimisation in scottish secondary schools: Same or separate entities? Aggressive Behavior, 28(1), 45-61. doi:10.1002/ab.90005.

Karlsson, E., Stickley, A., Lindblad, F., Schwab-Stone, M., Ruchkin, V., Institutionen för samhällsvetenskaper. . SCOHOST (Stockholm Centre on Health of Societies in Transition). (2014;2013;). Risk and protective factors for peer victimization: A 1-year follow-up study of urban American students. European Child \& Adolescent Psychiatry, 23(9), 773-781. doi:10.1007/s00787-013-0507-6.

Kashdan, T. B., Goodman, F. R., Mallard, T. T., \& DeWall, C. N. (2015). What triggers anger in everyday life? links to the intensity, control, and regulation of these emotions, and personality traits: Anger regulation in daily life. Journal of Personality, , n/a. doi:10.1111/jopy.12214.

Kendrick, K., Jutengren, G., Stattin, H., Örebro universitet, \& Institutionen för juridik, psykologi och socialt arbete. (2012). The protective role of supportive friends against bullying perpetration and victimization. Journal of Adolescence, 35(4), 1069-1080. doi:10.1016/j.adolescence.2012.02.014.

Kessel Schneider, S., O'Donnell, L., \& Smith, E. (2015). Trends in cyberbullying and school bullying victimization in a regional census of high school students, 2006- 2012. Journal of School Health, 85(9), 611-620. doi:10.1111/josh.12290. 
Running head: School-bullying and Cyber-bullying

Khamis, V. (2014;2015;). Bullying among school-age children in the greater beirut area: Risk and protective factors. Child Abuse \& Neglect, 39, 137-146. doi:10.1016/j.chiabu.2014.08.005.

Khanjani, Z., Mosanezhad Jeddi, E., Hekmati, I., Khalilzade, S., Etemadi Nia, M., Andalib, M., \& Ashrafian, P. (2015). Comparison of cognitive empathy, emotional empathy, and social functioning in different age groups. Australian Psychologist, 50(1), 80-85. doi:10.1111/ap.12099.

Khurana, A., Bleakley, A., Jordan, A. B., \& Romer, D. (2015). The protective effects of parental monitoring and internet restriction on adolescents' risk of online harassment. Journal of Youth and Adolescence, 44(5), 1039-1047. doi:10.1007/s10964-014-02424.

King, J. E., Walpole, C. E., \& Lamon, K. (2007). Surf and turf wars Online-Growing implications of internet gang violence. Journal of Adolescent Health, 41(6), S66-S68. doi:10.1016/j.jadohealth.2007.09.001.

Klein, W. (2015). Responding to bullying: Language socialization and religious identification in classes for sikh youth. Journal of Language, Identity \& Education, 14(1), 19-35. doi:10.1080/15348458.2015.988568.

Knopf, A. (2015). Cyberbullying linked to mental health problems in teens; protective factor seen in family dinners. The Brown University Child and Adolescent Behavior Letter, 31(1), 4-5. doi:10.1002/cbl.30012.

Kokkinos, C. M., Antoniadou, N., Asdre, A., \& Voulgaridou, K. (2016). Parenting and internet behavior predictors of cyber-bullying and cyber-victimization among preadolescents. Deviant Behavior, 37(4), 439. doi:10.1080/01639625.2015.1060087. 
Running head: School-bullying and Cyber-bullying

Kokkinos, C. M., Baltzidis, E., \& Xynogala, D. (2016). Prevalence and personality correlates of facebook bullying among university undergraduates. Computers in Human Behavior, 55, 840-850. doi:10.1016/j.chb.2015.10.017.

Kollerová, L., Janošová, P., \& Ř́í̌an, P. (2015). Moral motivation in defending classmates victimized by bullying. European Journal of Developmental Psychology, 12(3), 297309. doi:10.1080/17405629.2015.1006125.

Konishi, C., \& Hymel, S. (2009;2008;). Bullying and stress in early adolescence: The role of coping and social support. The Journal of Early Adolescence, 29(3), 333-356. doi:10.1177/0272431608320126.

Korenis, P., \& Billick, S. B. (2014). Forensic implications: Adolescent sexting and cyberbullying. Psychiatric Quarterly, 85(1), 97-101. doi:10.1007/s11126-013-9277-z.

Kowalski, R. M., \& Limber, S. P. (2013). Psychological, physical, and academic correlates of cyberbullying and traditional bullying. The Journal of Adolescent Health : Official Publication of the Society for Adolescent Medicine, 53(1 Suppl), S13. doi:10.1016/j.jadohealth.2012.09.018.

Kraft, E. M., \& Wang, J. (2009). Effectiveness of cyber bullying prevention strategies: A study on students' perspectives. International Journal of Cyber Criminology, 3(2), 513.

Krienert, J. L., \& Walsh, J. A. (2011). My brother's keeper: A contemporary examination of reported sibling violence using national level data, 2000-2005. Journal of Family Violence, 26(5), 331. doi:10.1007/s10896-011-9367-3.

Kumpulainen, K., Räsänen, E., \& Puura, K. (2001). Psychiatric disorders and the use of mental health services among children involved in bullying. Aggressive Behavior, 27(2), 102-110. doi:10.1002/ab.3. 
Running head: School-bullying and Cyber-bullying

Lansu, T. A. M., Cillessen, A. H. N., \& Bukowski, W. M. (2013). Implicit and explicit peer evaluation: Associations with early adolescents' prosociality, aggression, and bullying. Journal of Research on Adolescence, 23(4), 762-771. doi:10.1111/jora.12028.

Lapidot-Lefler, N., \& Barak, A. (2012). Effects of anonymity, invisibility, and lack of eyecontact on toxic online disinhibition. Computers in Human Behavior, 28(2), 434-443. doi:10.1016/j.chb.2011.10.014.

Lee, E. (2009). The relationship of aggression and bullying to social preference: Differences in gender and types of aggression. International Journal of Behavioral Development, 33(4), 323-330. doi:10.1177/0165025408098028.

Lehman, B. (2014). Gender differences in bullying victimization: The role of academics and school context. Sociological Spectrum, 34(6), 549-570. doi:10.1080/02732173.2014.947454.

Lenhart, A., Madden, M., Macgill, A. R., \& Smith, A. (2007). Teens and social media. Retrieved from Pew Internet and American Life Project: http://pewinternet.org/PPF/r/230/report display.asp.

Leung, L., \& Lee, P. S. N. (2012). The influences of information literacy, internet addiction and parenting styles on internet risks. New Media \& Society, 14(1), 117-136. doi:10.1177/1461444811410406.

Li, C. K. W., Holt, T. J., Bossler, A. M., \& May, D. C. (2016). Examining the mediating effects of social learning on the low self-control-cyberbullying relationship in a youth sample. Deviant Behavior, 37(2), 126. doi:10.1080/01639625.2014.1004023.

Lonigro, A., Schneider, B. H., Laghi, F., Baiocco, R., Pallini, S., \& Brunner, T. (2015). Is cyberbullying related to trait or state anger? Child Psychiatry \& Human Development, 46(3), 445-454. doi:10.1007/s10578-014-0484-0. 
Running head: School-bullying and Cyber-bullying

Losel, F., \& Bender, D. (2014). Aggressive, delinquent, and violent outcomes of school bullying: Do family and individual factors have a protective function? Journal of School Violence, 13(1), 59-79. doi:10.1080/15388220.2013.840644.

Loukas, A., \& Pasch, K. E. (2013). Does school connectedness buffer the impact of peer victimization on early adolescents' subsequent adjustment problems? The Journal of Early Adolescence, 33(2), 245-266. doi:10.1177/0272431611435117.

Low, S., \& Espelage, D. (2013). Differentiating cyber bullying perpetration from nonphysical bullying: Commonalities across race, individual, and family predictors. Psychology of Violence, 3(1), 39-52. doi:10.1037/a0030308.

MacDonald, C. D., \& Roberts-Pittman, B. (2010). Cyberbullying among college students: Prevalence and demographic differences. Procedia - Social and Behavioral Sciences, 9, 2003-2009. doi:10.1016/j.sbspro.2010.12.436.

Machackova, H., \& Pfetsch, J. (2016). Bystanders' responses to offline bullying and cyberbullying: The role of empathy and normative beliefs about aggression. Scandinavian Journal of Psychology, 57(2), 169-176. doi:10.1111/sjop.12277.

Malik, A., \& Mehta, M. (2016). Bullying among adolescents in an indian school. Psychological Studies, 61(3), 220-232. doi:10.1007/s12646-016-0368-4.

Mann, M. J., Kristjansson, A. L., Sigfusdottir, I. D., \& Smith, M. L. (2015). The role of community, family, peer, and school factors in group bullying: Implications for School- Based intervention. Journal of School Health, 85(7), 477-486. doi:10.1111/josh.12270.

Marcum, C. D., Higgins, G. E., Freiburger, T. L., \& Ricketts, M. L. (2014). Exploration of the cyberbullying Victim/Offender overlap by sex. American Journal of Criminal Justice, 39(3), 538-548. doi:10.1007/s12103-013-9217-3. 
Running head: School-bullying and Cyber-bullying

Marini, Z. A., Dane, A. V., \& Bosacki, S. L. (2006). Direct and indirect bully-victims: Differential psychosocial risk factors associated with adolescents involved in bullying and victimization. Aggressive Behavior, 32(6), 551-569. doi:10.1002/ab.20155.

Mark, L., \& Ratliffe, K. (2011). Cyber worlds: New playgrounds for bullying. Computers in the Schools, 28(2), 92-116. doi:10.1080/07380569.2011.575753.

Matsunaga, M. (2009). Parents Don’t (always) know their children have been bullied: Childparent discrepancy on bullying and family-level profile of communication standards. Human Communication Research, 35(2), 221-247. doi:10.1111/j.14682958.2009.01345.x.

Mazzone, A., Camodeca, M., \& Salmivalli, C. (2016)a. Interactive effects of guilt and moral disengagement on bullying, defending and outsider behavior. Journal of Moral Education, 1-14. doi:10.1080/03057240.2016.1216399.

Mazzone, A., Camodeca, M., \& Salmivalli, C. (2016)b. Stability and change of outsider behavior in school bullying: The role of shame and guilt in a longitudinal perspective. The Journal of Early Adolescence, doi:10.1177/0272431616659560.

McMahon, E. M., Reulbach, U., Keeley, H., Perry, I. J., \& Arensman, E. (2010). Bullying victimisation, self harm and associated factors in irish adolescent boys. Social Science \& Medicine, 71(7), 1300-1307. doi:10.1016/j.socscimed.2010.06.034.

Menesini, E., \& Camodeca, M. (2008). Shame and guilt as behaviour regulators: Relationships with bullying, victimization and prosocial behaviour. British Journal of Developmental Psychology, 26(2), 183-196. doi:10.1348/026151007X205281.

Menesini, E., Nocentini, A., \& Camodeca, M. (2013). Morality, values, traditional bullying, and cyberbullying in adolescence: Morality and values in cyber and traditional bullying. British Journal of Developmental Psychology, 31(1), 1-14. doi:10.1111/j.2044-835X.2011.02066.x. 
Running head: School-bullying and Cyber-bullying

Menesini, E., Sanchez, V., Fonzi, A., Ortega, R., Costabile, A., \& Lo Feudo, G. (2003). Moral emotions and bullying: A cross- national comparison of differences between bullies, victims and outsiders. Aggressive Behavior, 29(6), 515-530. doi:10.1002/ab.10060.

Merrill, R. M., \& Hanson, C. L. (2016). Risk and protective factors associated with being bullied on school property compared with cyberbullied. BMC Public Health, 16(1), 145.

Messias, E., Kindrick, K., \& Castro, J. (2014). School bullying, cyberbullying, or both: Correlates of teen suicidality in the 2011 CDC youth risk behavior survey. Comprehensive Psychiatry, 55(5), 1063-1068. doi:10.1016/j.comppsych.2014.02.005.

Mishna, F., Cook, C., Gadalla, T., Daciuk, J., \& Solomon, S. (2010). Cyber bullying behaviors among middle and high school students. American Journal of Orthopsychiatry, 80(3), 362-374. doi:10.1111/j.1939-0025.2010.01040.x.

Mishna, F., Khoury-Kassabri, M., Gadalla, T., \& Daciuk, J. (2012). Risk factors for involvement in cyber bullying: Victims, bullies and bully-victims. Children and Youth Services Review, 34(1), 63-70. doi:10.1016/j.childyouth.2011.08.032.

Mishna, F., Saini, M., \& Solomon, S. (2009). Ongoing and online: Children and youth's perceptions of cyber bullying. Children and Youth Services Review, 31(12), 12221228. doi:10.1016/j.childyouth.2009.05.004.

Mishna, F., Wiener, J., \& Pepler, D. (2008). Some of my best Friends-Experiences of bullying within friendships. School Psychology International, 29(5), 549-573. doi:10.1177/0143034308099201.

Mitsopoulou, E., \& Giovazolias, T. (2015). Personality traits, empathy and bullying behavior: A meta-analytic approach. Aggression and Violent Behavior, 21, 61-72. doi:10.1016/j.avb.2015.01.007. 
Running head: School-bullying and Cyber-bullying

Mlisa, L. N., Ward, C. L., Flisher, A. J., \& Lombard, C. J. (2008). Bullying at rural high schools in the eastern cape province, south africa: Prevalence, and risk and protective factors at school and in the family. Journal of Psychology in Africa, 18(2), 261. doi:10.1080/14330237.2008.10820195.

Modecki, K. L., Minchin, J., Harbaugh, A. G., Guerra, N. G., \& Runions, K. C. (2014). Bullying prevalence across contexts: A meta-analysis measuring cyber and traditional bullying. Journal of Adolescent Health, 55(5), 602-611. doi:10.1016/j.jadohealth.2014.06.007.

Moon, B., \& Alarid, L. F. (2015). School bullying, low self-control, and opportunity. Journal of Interpersonal Violence, 30(5), 839-856. doi:10.1177/0886260514536281.

Morahan-Martin, J., \& Schumacher, P. (2003). Loneliness and social uses of the internet. Computers in Human Behavior, 19(6), 659-671. doi:10.1016/S0747-5632(03)000402.

Morin, K. H., Bradshaw, P. C., \& Berg, K. J. (2015). Examining the link between peer victimization and adjustment problems in adolescents: The role of connectedness and parent engagement. Psychology of Violence, 5(4), 422-432. doi:10.1037/a0039798.

Mueller, A. S., James, W., Abrutyn, S., \& Levin, M. L. (2015). Suicide ideation and bullying among US adolescents: Examining the intersections of sexual orientation, gender, and race/ethnicity. American Journal of Public Health, 105(5), 980-985. doi:10.2105/AJPH.2014.302391.

Muñoz, L. C., Qualter, P., \& Padgett, G. (2011). Empathy and bullying: Exploring the influence of callous-unemotional traits. Child Psychiatry \& Human Development, 42(2), 183-196. doi:10.1007/s10578-010-0206-1. 
Running head: School-bullying and Cyber-bullying

Mura, G., Topcu, C., Erdur-Baker, O., \& Diamantini, D. (2011). An international study of cyber bullying perception and diffusion among adolescents. Procedia - Social and Behavioral Sciences, 15, 3805-3809. doi:10.1016/j.sbspro.2011.04.377.

Navarro, R., Yubero, S., \& Larranaga, E. (2015). Psychosocial risk factors for involvement in bullying behaviors: Empirical comparison between cyberbullying and social bullying victims and bullies. School Mental Health, 7(4), 235-248. doi:10.1007/s12310-0159157-9.

Newman, M., Woodcock, A., \& Dunham, P. (2006). 'playtime in the borderlands': Children's representations of school, gender and bullying through photographs and interviews. Children's Geographies, 4(3), 289-302. doi:10.1080/14733280601005617.

Nilan, P., Burgess, H., Hobbs, M., Threadgold, S., \& Alexander, W. (2015). Youth, social media, and cyberbullying among australian youth: "Sick friends". Social Media + Society, 1(2) doi:10.1177/2056305115604848.

Nishina, A., Witkow, M. R., \& Juvonen, J. (2005). Sticks and stones may break my bones, but names will make me feel sick: The psychosocial, somatic, and scholastic consequences of peer harassment. Journal of Clinical Child \& Adolescent Psychology, 34(1), 37-48. doi:10.1207/s15374424jccp3401_4.

Noorden, T. H. J. v., Haselager, G. J. T., Cillessen, A. H. N., \& Bukowski, W. M. (2015). Empathy and involvement in bullying in children and adolescents: A systematic review. Journal of Youth and Adolescence, 44(3), 637-657. doi:10.1007/s10964-0140135-6.

Nuccitelli, M. (2012). 2012 cyber bullying tactics. Forensic Examiner, 21(3), 24.

O’Moore, M., \& Kirkham, C. (2001). Self- esteem and its relationship to bullying behaviour. Aggressive Behavior, 27(4), 269-283. doi:10.1002/ab.1010. 
Running head: School-bullying and Cyber-bullying

Obermann, M. (2011). Moral disengagement in self- reported and peer- nominated school bullying. Aggressive Behavior, 37(2), 133-144. doi:10.1002/ab.20378.

Olthof, T. (2012). Anticipated feelings of guilt and shame as predictors of early adolescents' antisocial and prosocial interpersonal behaviour. European Journal of Developmental Psychology, 9(3), 371-388. doi:10.1080/17405629.2012.680300.

Oluyinka, O. A. (2008). Social-psychological factors associated with bullying behaviour among secondary school students. Journal of Psychology in Africa, 18(2), 269. doi:10.1080/14330237.2008.10820196.

Olweus, D. (1993). Bullying at school: What we know and what we can do. Oxford, UK: Blackwell Publishers.

Olweus, D. (2003). A profile of bullying at school. Educational Leadership, 60, 12-17. Retrieved from http://www.lhsenglish.com/uploads/7/9/0/8/7908073/olweus_profile_of_bullying.pdf.

Özgür, H. (2016). The relationship between internet parenting styles and internet usage of children and adolescents. Computers in Human Behavior, 60, 411-424. doi:10.1016/j.chb.2016.02.081.

Parris, L., Varjas, K., Meyers, J., \& Cutts, H. (2012;2011;). High school students’ perceptions of coping with cyberbullying. Youth \& Society, 44(2), 284-306. doi:10.1177/0044118X11398881.

Patchin, J. W., \& Hinduja, S. (2010). Cyberbullying and Self- Esteem. Journal of School Health, 80(12), 614-621. doi:10.1111/j.1746-1561.2010.00548.x.

Pellegrini, A. D., Bartini, M., \& Brooks, F. (1999). School bullies, victims, and aggressive victims: Factors relating to group affiliation and victimization in early adolescence. Journal of Educational Psychology, 91(2), 216-224. doi:10.1037/0022-0663.91.2.216. 
Running head: School-bullying and Cyber-bullying

Pengpid, S., \& Peltzer, K. (2013). Bullying and its associated factors among school-aged adolescents in Thailand. The Scientific World Journal, 2013, 254083-6. doi:10.1155/2013/254083.

Pepler, D., Jiang, D., Craig, W., \& Connolly, J. (2008). Developmental trajectories of bullying and associated factors. Child Development, 79(2), 325-338. doi:10.1111/j.1467-8624.2007.01128.x.

Perren, S., \& Gutzwiller-Helfenfinger, E. (2012). Cyberbullying and traditional bullying in adolescence: Differential roles of moral disengagement, moral emotions, and moral values. European Journal of Developmental Psychology, 9(2), 195. doi:10.1080/17405629.2011.643168.

Polan, J. C., Sieving, R. E., \& McMorris, B. J. (2013). Are young adolescents' social and emotional skills protective against involvement in violence and bullying behaviors? Health Promotion Practice, 14(4), 599-606.

Pollastri, A. R., Cardemil, E. V., \& O’Donnell, E. H. (2010). Self-esteem in pure bullies and Bully/Victims: A longitudinal analysis. Journal of Interpersonal Violence, 25(8), 1489-1502. doi:10.1177/0886260509354579.

Pornari, C. D., \& Wood, J. (2010). Peer and cyber aggression in secondary school students: The role of moral disengagement, hostile attribution bias, and outcome expectancies. Aggressive Behavior, 36(2), 81. doi:10.1002/ab.20336.

Pozzoli, T., Gini, G., \& Vieno, A. (2012). Individual and class moral disengagement in bullying among elementary school children. Aggressive Behavior, 38(5), 378-388. doi:10.1002/ab.21442.

Price, M. (2012). Morality: What is it good for? Global Custodian. Retrieved from https://hud.summon.serialssolutions.com/search? 
Running head: School-bullying and Cyber-bullying

Puhl, R. M., \& King, K. M. (2013). Weight discrimination and bullying. Best Practice and Research: Clinical Endocrinology and Metabolism, 27(2), 117-127. doi:10.1016/j.beem.2012.12.002.

Pyżalski, J. (2012). From cyberbullying to electronic aggression: Typology of the phenomenon. Emotional and Behavioural Difficulties, 17(3-4), 305. doi:10.1080/13632752.2012.704319.

Rachoene, M., \& Oyedemi, T. (2015). From self-expression to social aggression: Cyberbullying culture among south african youth on facebook. Communication, 41(3), 302-319. doi:10.1080/02500167.2015.1093325.

Rafferty, R., \& Vander Ven, T. (2014). "I hate everything about you”: A qualitative examination of cyberbullying and on-line aggression in a college sample. Deviant Behavior, 35(5), 364-377. doi:10.1080/01639625.2013.849171.

Rajendran, K., Kruszewski, E., \& Halperin, J. M. (2016). Parenting style influences bullying: A longitudinal study comparing children with and without behavioral problems. Journal of Child Psychology and Psychiatry, 57(2), 188-195. doi:10.1111/jcpp.12433.

Ramírez, J. M., \& Andreu, J. M. (2006). Aggression, and some related psychological constructs (anger, hostility, and impulsivity) some comments from a research project. Neuroscience and Biobehavioral Reviews, 30(3), 276-291. doi:10.1016/j.neubiorev.2005.04.015.

Ramirez, O. (2013). Survivors of school bullying: A collective case study. Children \& Schools, 35(2), 93-99. doi:10.1093/cs/cdt001.

Raskauskas, J. (2009; 2010;). Text-bullying: Associations with traditional bullying and depression among new Zealand adolescents. Journal of School Violence, 9(1), 74-97. doi:10.1080/15388220903185605. 
Running head: School-bullying and Cyber-bullying

Reijntjes, A., Kamphuis, J. H., Prinzie, P., \& Telch, M. J. (2010). Peer victimization and internalizing problems in children: A meta-analysis of longitudinal studies. Child Abuse \& Neglect, 34(4), 244-252. doi:10.1016/j.chiabu.2009.07.009.

Rieffe, C., Camodeca, M., Pouw, L. B. C., Lange, A. M. C., \& Stockmann, L. (2012). Don't anger me! bullying, victimization, and emotion dysregulation in young adolescents with ASD. European Journal of Developmental Psychology, 9(3), 351. doi:10.1080/17405629.2012.680302.

Rigby, K. (2002). New perspectives on bullying. London, UK: Jessica Kingsley.

Rigby, K. (2007). Bullying in schools and what to do about it: Revised and updated. Australian Council for Educational Research. London, UK: Jessica Kingsley.

Rigby, K., \& Cox, I. (1996). The contribution of bullying at school and low self-esteem to acts of delinquency among australian teenagers. Personality and Individual Differences, 21(4), 609-612. doi:10.1016/0191-8869(96)00105-5.

Rigby, K., \& Smith, P. K. (2011). Is school bullying really on the rise? Social Psychology of Education, 14(4), 441-455. doi:10.1007/s11218-011-9158-y.

Rivers, I., \& Noret, N. (2010). 'I h8 u': Findings from a five-year study of text and email bullying. British Educational Research Journal, 36(4), 643-671. doi:10.1080/01411920903071918.

Roberts, W., Strayer, J., \& Denham, S. (2014). Empathy, anger, guilt: Emotions and prosocial behaviour. Canadian Journal of Behavioural Science / Revue Canadienne Des Sciences Du Comportement, 46(4), 465-474. doi:10.1037/a0035057.

Robson, C., \& Witenberg, R. T. (2013). The influence of moral disengagement, morally based self-esteem, age, and gender on traditional bullying and cyberbullying. Journal of School Violence, 12(2), 211-231. doi:10.1080/15388220.2012.762921. 
Running head: School-bullying and Cyber-bullying

Rokach, A. (2000). Offence type and the experience of loneliness. International Journal of Offender Therapy and Comparative Criminology, 44(5), 549-563. doi:10.1177/0306624X00445003.

Rokach, A. (2001). Criminal offense type and the causes of loneliness. The Journal of Psychology, 135(3), 277-291. doi:10.1080/00223980109603698.

Roland, E. (2002). Aggression, depression, and bullying others. Aggressive Behaviour, 28(3), 198-206. doi:10.1002/ab.90022.

Roland, E., \& Idsøe, T. (2001). Aggression and bullying. Aggressive Behavior, 27(6), 446462. doi:10.1002/ab.1029.

Rosan, A. M., \& Costea-Barlutiu, C. (2013). associations between callous-unemotional traits, aggression and psychopathology in detained adolescent males. Journal of Cognitive and Behavioral Psychotherapies, 13(2), 397.

Rose, C. A., \& Espelage, D. L. (2012). Risk and protective factors associated with the bullying involvement of students with emotional and behavioral disorders. Behavioral Disorders, 37(3), 133-148.

Rose, C. A., Simpson, C. G., \& Ellis, S. K. (2016). The relationship between school belonging, sibling aggression and bullying involvement: Implications for students with and without disabilities. Educational Psychology, 36(8), 1462-1486. doi:10.1080/01443410.2015.1066757.

Runions, K. C., \& Bak, M. (2015). Online moral disengagement, cyberbullying, and cyberaggression. Cyberpsychology, Behavior, and Social Networking, 18(7), 4-405. doi:10.1089/cyber.2014.0670.

Russell, S. T., Day, J. K., Ioverno, S., \& Toomey, R. B. (2016). Are school policies focused on sexual orientation and gender identity associated with less bullying? teachers' perspectives. Journal of School Psychology, 54, 29-38. doi:10.1016/j.jsp.2015.10.005. 
Running head: School-bullying and Cyber-bullying

Salmivalli, C., Kaukiainen, A., Kaistaniemi, L., \& Lagerspetz, K. M. J. (1999). Selfevaluated self-esteem, peer-evaluated self-esteem, and defensive egotism as predictors of adolescents' participation in bullying situations. Personality and Social Psychology Bulletin, 25(10), 1268-1278. doi:10.1177/0146167299258008.

Salmivalli, C., Sentse, M., Dijkstra, J. K., \& Cillessen, A. H. N. (2013). The dynamics of friendships and victimization in adolescence: A longitudinal social network perspective. Aggressive Behavior, 39(3), 229-238. doi:10.1002/ab.21469.

Sapouna, M., \& Wolke, D. (2013). Resilience to bullying victimization: The role of individual, family and peer characteristics. Child Abuse \& Neglect, 37(11), 997. doi:10.1016/j.chiabu.2013.05.009.

Scheithauer, H., Hayer, T., \& Petermann, F. (2006). Physical, verbal, and relational forms of bullying among German students: Age trends, gender differences, and correlates. Aggressive Behavior, 32(3), 261-275. doi:10.1002/ab.20128.

Schultze- Krumbholz, A., Schultze, M., Zagorscak, P., Wölfer, R., \& Scheithauer, H. $(2016 ; 2015 ;)$. Feeling cybervictims' pain-The effect of empathy training on cyberbullying. Aggressive Behavior, 42(2), 147-156. doi:10.1002/ab.21613.

Schwartz, D., McFadyen-Ketchum, S., Dodge, K. A., Pettit, G. S., \& Bates, J. E. (1999). Early behavior problems as a predictor of later peer group victimization: Moderators and mediators in the pathways of social risk. Journal of Abnormal Child Psychology, 27(3), 191-201. doi:10.1023/A:1021948206165.

Seeds, P., Harkness, K., \& Quilty, L. (2010). Parental maltreatment, bullying, and adolescent depression: Evidence for the mediating role of perceived social support. Journal of Clinical Child \& Adolescent Psychology, 39(5), 681-692. doi:10.1080/15374416.2010.501289. 
Running head: School-bullying and Cyber-bullying

Sentse, M., Kretschmer, T., \& Salmivalli, C. (2015). The longitudinal interplay between bullying, victimization, and social status: Age-related and gender differences. Social Development, 24(3), 659-677. doi:10.1111/sode.12115.

Shetgiri, R., Lin, H., \& Flores, G. (2013;2012;). Trends in risk and protective factors for child bullying perpetration in the united states. Child Psychiatry \& Human Development, 44(1), 89-104. doi:10.1007/s10578-012-0312-3.

Shetgiri, R., Lin, H., \& Flores, G. (2015;2014;). Suboptimal maternal and paternal mental health are associated with child bullying perpetration. Child Psychiatry \& Human Development, 46(3), 455-465. doi:10.1007/s10578-014-0485-z.

Sigfusdottir, I. D., Gudjonsson, G. H., \& Sigurdsson, J. F. (2010). Bullying and delinquency. the mediating role of anger. Personality and Individual Differences, 48(4), 391-396. doi:10.1016/j.paid.2009.10.034.

Sims-Schouten, W. (2015). Bullying in early childhood and the construction of young children as premoral agents: Implications for practice. Pastoral Care in Education, 33(4), 234-245. doi:10.1080/02643944.2015.1094121.

Singer, T., \& Lamm, C. (2009). The social neuroscience of empathy. Annals of the New York Academy of Sciences, 1156(1), 81-96. doi:10.1111/j.1749-6632.2009.04418.x.

Skinner, J. A., \& Kowalski, R. M. (2013). Profiles of sibling bullying. Journal of Interpersonal Violence, 28(8), 1726-1736. doi:10.1177/0886260512468327.

Slonje, R., Smith, P. K., Frisen, A., Department of Psychology, Psykologiska institutionen, Samhällsvetenskapliga fakulteten. . Göteborgs universitet. (2013). The nature of cyberbullying, and strategies for prevention. Computers in Human Behavior, 29(1), 26-32.

Smith, A. (2006). Cognitive empathy and emotional empathy in human behavior and evolution. The Psychological Record, 56(1), 3. 
Running head: School-bullying and Cyber-bullying

Smits, D. J. M., \& Kuppens, P. (2005). The relations between anger, coping with anger, and aggression, and the BIS/BAS system. Personality and Individual Differences, 39(4), 783-793. doi:10.1016/j.paid.2005.02.023.

Sourander, A., Helstelä, L., Helenius, H., \& Piha, J. (2000). Persistence of bullying from childhood to adolescence — a longitudinal 8-year follow-up study. Child Abuse \& Neglect, 24(7), 873-881. doi:10.1016/S0145-2134(00)00146-0.

Spies Shapiro, L. A., \& Margolin, G. (2014). Growing up wired: Social networking sites and adolescent psychosocial development. Clinical Child and Family Psychology Review, 17(1), 1-18. doi:10.1007/s10567-013-0135-1.

Stavrinides, P., Georgiou, S., \& Theofanous, V. (2010). Bullying and empathy: A short-term longitudinal investigation. Educational Psychology, 30(7), 793-802. doi:10.1080/01443410.2010.506004.

Stephenson, P., \& Smith, D. (1989). Bullying in two English comprehensive schools. In E. Roland \& E. Munthe (Eds.), Bullying: An International Perspective. London: Fulton.

Sticca, F., Ruggieri, S., Alsaker, F., \& Perren, S. (2013). Longitudinal risk factors for cyberbullying in adolescence. Journal of Community \& Applied Social Psychology, 23(1), 52-67. doi:10.1002/casp.2136.

Talwar, V., Gomez-Garibello, C., \& Shariff, S. (2014). Adolescents' moral evaluations and ratings of cyberbullying: The effect of veracity and intentionality behind the event. Computers in Human Behavior, 36, 122-128. doi:10.1016/j.chb.2014.03.046.

Tanrikulu, I., \& Campbell, M. A. (2015). Sibling bullying perpetration: Associations with gender, grade, peer perpetration, trait anger, and moral disengagement. Journal of Interpersonal Violence, 30(6), 1010-1024. doi:10.1177/0886260514539763.

Tarablus, T., Heiman, T., \& Olenik-Shemesh, D. (2015). Cyber bullying among teenagers in israel: An examination of cyber bullying, traditional bullying, and socioemotional 
Running head: School-bullying and Cyber-bullying

functioning. Journal of Aggression, Maltreatment \& Trauma, 24(6), 707. doi:10.1080/10926771.2015.1049763.

Tenenbaum, L. S., Varjas, K., Meyers, J., \& Parris, L. (2011). Coping strategies and perceived effectiveness in fourth through eighth grade victims of bullying. School Psychology International, 32(3), 263-287. doi:10.1177/0143034311402309.

Thompson, L., \& Cupples, J. (2008). Seen and not heard? text messaging and digital sociality. Social \& Cultural Geography, 9(1), 95-108. doi:10.1080/14649360701789634.

Thompson, P. (2013). 'it really hurts and it is bullying': Moral learning as political practice. Journal of Moral Education, 42(2), 224.

Thornberg, R., Jungert, T., Linköpings universitet, Pedagogik och didaktik, Institutionen för beteendevetenskap och lärande, Psykologi, . . Filosofiska fakulteten. (2014). School bullying and the mechanisms of moral disengagement. Aggressive Behavior, 40(2), 99-108. doi:10.1002/ab.21509.

Thornberg, R., Rosenqvist, R., Johansson, P., Pedagogik och didaktik, Linköpings universitet, Institutionen för beteendevetenskap och lärande, \& Utbildningsvetenskap. (2012). Older teenagers' explanations of bullying. Child \& Youth Care Forum, 41(4), 327-342. doi:10.1007/s10566-012-9171-0.

Thornton, L. C., Frick, P. J., Crapanzano, A. M., \& Terranova, A. M. (2013). The incremental utility of callous-unemotional traits and conduct problems in predicting aggression and bullying in a community sample of boys and girls. Psychological Assessment, 25(2), 366-378. doi:10.1037/a0031153.

Tippett, N., \& Wolke, D. (2015). Aggression between siblings: Associations with the home environment and peer bullying: Aggression between siblings. Aggressive Behavior, 41(1), 14-24. doi:10.1002/ab.21557. 
Running head: School-bullying and Cyber-bullying

Topcu, C., \& Erdur-Baker, O. (2010). The revised cyber bullying inventory (RCBI): Validity and reliability studies. Procedia - Social and Behavioral Sciences, 5, 660-664. doi:10.1016/j.sbspro.2010.07.161.

Topcu, C., \& Erdur-Baker, O. (2012). Affective and cognitive empathy as mediators of gender differences in cyber and traditional bullying. School Psychology International, 33(5), 550-561. doi:10.1177/0143034312446882.

Topcu, Ç., Yıldırım, A., \& Erdur-Baker, O. (2013). Cyber bullying @ schools: What do Turkish adolescents think? International Journal for the Advancement of Counselling, 35(2), 139-151. doi:10.1007/s10447-012-9173-5.

Tsaousis, I. (2016). The relationship of self-esteem to bullying perpetration and peer victimization among schoolchildren and adolescents: A meta-analytic review. Aggression and Violent Behavior, doi:10.1016/j.avb.2016.09.005.

Ttofi, M. M., \& Farrington, D. P. (2008). Reintegrative shaming theory, moral emotions and bullying. Aggressive Behavior, 34(4), 352-368. doi:10.1002/ab.20257.

Tucker, C. J., Finkelhor, D., Turner, H., \& Shattuck, A. M. (2014). Sibling and peer victimization in childhood and adolescence. Child Abuse \& Neglect, 38(10), 15991606. doi:10.1016/j.chiabu.2014.05.007.

Turan, N., Polat, O., Karapirli, M., Uysal, C., \& Turan, S. G. (2011). The new violence type of the era: Cyber bullying among university students: Violence among university students. Neurology Psychiatry and Brain Research, 17(1), 21-26. doi:10.1016/j.npbr.2011.02.005.

Turner, K. A., \& White, B. A. (2015). Contingent on contingencies: Connections between anger rumination, self-esteem, and aggression. Personality and Individual Differences, 82, 199-202. doi:10.1016/j.paid.2015.03.023. 
Running head: School-bullying and Cyber-bullying

Unnever, J. D., \& Cornell, D. G. (2003). Bullying, self-control, and adhd. Journal of Interpersonal Violence, 18(2), 129-147. doi:10.1177/0886260502238731.

Valcke, M., Bonte, S., De Wever, B., \& Rots, I. (2010). Internet parenting styles and the impact on internet use of primary school children. Computers \& Education, 55(2), 454-464. doi:10.1016/j.compedu.2010.02.009.

Van der Wal, Marcel F. (2005). There is bullying and bullying. European Journal of Pediatrics, 164(2), 117-118. doi:10.1007/s00431-004-1573-z.

van der Watt, R. (2014). Attachment, parenting styles and bullying during pubertal years. Journal of Child \& Adolescent Mental Health, 26(3), 251. doi:10.2989/17280583.2014.947966.

Vazsonyi, A. T., Machackova, H., Sevcikova, A., Smahel, D., \& Cerna, A. (2012). Cyberbullying in context: Direct and indirect effects by low self-control across 25 european countries. European Journal of Developmental Psychology, 9(2), 210. doi:10.1080/17405629.2011.644919.

Vickers, M. H. (2009). Bullying, disability and work: A case study of workplace bullying. Qualitative Research in Organizations and Management: An International Journal, 4(3), 255-272. doi:10.1108/17465640911002536.

Wang, X., Lei, L., Liu, D., \& Hu, H. (2016). Moderating effects of moral reasoning and gender on the relation between moral disengagement and cyberbullying in adolescents. Personality and Individual Differences, 98, 244-249. doi:10.1016/j.paid.2016.04.056.

Warden, D., \& Mackinnon, S. (2003). Prosocial children, bullies and victims: An investigation of their sociometric status, empathy and social problem-solving strategies. The British Journal of Developmental Psychology, 21, 367. 
Running head: School-bullying and Cyber-bullying

Weber, M., Ziegele, M., \& Schnauber, A. (2013). Blaming the victim: The effects of extraversion and information disclosure on guilt attributions in cyberbullying. Cyberpsychology, Behavior, and Social Networking, 16(4), 254-259. doi:10.1089/cyber.2012.0328.

Wienke Totura, C. M., MacKinnon-Lewis, C., Gesten, E. L., Gadd, R., Divine, K. P., Dunham, S., \& Kamboukos, D. (2009;2008;). Bullying and victimization among boys and girls in middle school: The influence of perceived family and school contexts. The Journal of Early Adolescence, 29(4), 571-609. doi:10.1177/0272431608324190.

Wilkowski, B. M., \& Robinson, M. D. (2008;2007;). The cognitive basis of trait anger and reactive aggression: An integrative analysis. Personality and Social Psychology Review, 12(1), 3-21. doi:10.1177/1088868307309874.

Willard, N. (2004). I can't see you, You can't see me. How the use of information and communication technologies can impact responsible behaviour. Retrieved 5, July, 2013, from http://www.cyberbully.org/ docs/disinhibition.pdf .

Willard, N. (2006). Flame retardant: Cyberbullies torment their victims 24/7: Here's how to stop the abuse. School Library Journal, 52, 54-56. Retrieved from http://search.proquest.com.libaccess.hud.ac.uk/docview/211826663?accountid=11526

Williams, K. R., \& Guerra, N. G. (2007). Prevalence and predictors of internet bullying. Journal of Adolescent Health, 41(6), S14-S21. doi:10.1016/j.jadohealth.2007.08.018.

Woods, S., Done, J., \& Kalsi, H. (2009). Peer victimisation and internalising difficulties: The moderating role of friendship quality. Journal of Adolescence, 32(2), 293-308. doi:10.1016/j.adolescence.2008.03.005. 
Running head: School-bullying and Cyber-bullying

Workman, M. (2012). Rash impulsivity, vengefulness, virtual-self and amplification of ethical relativism on cyber-smearing against corporations. Computers in Human Behavior, 28(1), 217. doi:10.1016/j.chb.2011.09.003.

Yang, S., Stewart, R., Kim, J., Kim, S., Shin, I., Dewey, M. E.. . Yoon, J. (2013). Differences in predictors of traditional and cyber-bullying: A 2-year longitudinal study in Korean school children. European Child \& Adolescent Psychiatry, 22(5), 309-318. doi:10.1007/s00787-012-0374-6.

Yilmaz, H. (2011). Cyberbullying in turkish middle schools: An exploratory study. School Psychology International, 32(6), 645-654. doi:10.1177/0143034311410262.

You, S., \& Lim, S. A. (2016). Longitudinal predictors of cyberbullying perpetration: Evidence from korean middle school students. Personality and Individual Differences, 89, 172-176. doi:10.1016/j.paid.2015.10.019. 